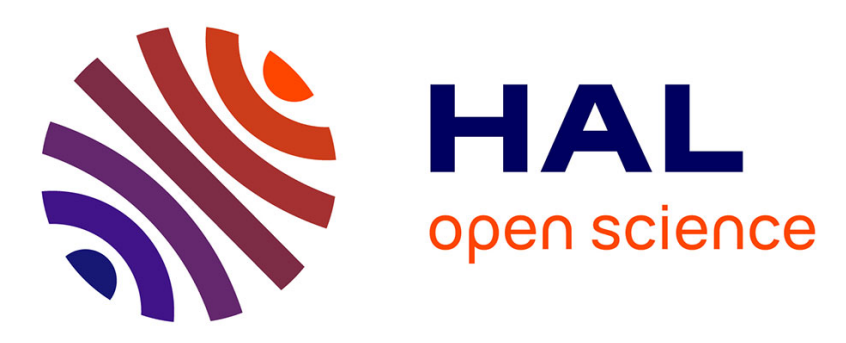

\title{
Impact of selenite and selenate on differentially expressed genes in rat liver examined by microarray analysis
}

Astrid C Bosse, Josef Pallauf, Bettina Hommel, Mariana Sturm, Nicole M Wolf, Susanne Fischer, Andreas S Mueller

\section{To cite this version:}

Astrid C Bosse, Josef Pallauf, Bettina Hommel, Mariana Sturm, Nicole M Wolf, et al.. Impact of selenite and selenate on differentially expressed genes in rat liver examined by microarray analysis. Bioscience Reports, 2010, 30 (5), pp.293-306. 10.1042/BSR20090089 . hal-00479318

\section{HAL Id: hal-00479318 https://hal.science/hal-00479318}

Submitted on 30 Apr 2010

HAL is a multi-disciplinary open access archive for the deposit and dissemination of scientific research documents, whether they are published or not. The documents may come from teaching and research institutions in France or abroad, or from public or private research centers.
L'archive ouverte pluridisciplinaire HAL, est destinée au dépôt et à la diffusion de documents scientifiques de niveau recherche, publiés ou non, émanant des établissements d'enseignement et de recherche français ou étrangers, des laboratoires publics ou privés. 
1 Impact of selenite and selenate on differentially expressed genes in rat liver examined 2 by microarray analysis

3

4 Astrid C. BOSSE ${ }^{1 \#)}$, Josef PALLAUF ${ }^{1 \#)}$, Bettina HOMMEL ${ }^{2 \#)}$, Mariana STURM ${ }^{2 \#)}$, Susanne

5 FISCHER ${ }^{2 \#)}$, Nicole M. WOLF ${ }^{2 \#)}$ and Andreas S. MUELLER ${ }^{2 \#) *}$

6

7

Short (page heading) title: Selenium and differential gene expression

* Corresponding author:

23 Andreas S. Mueller

24 Institute of Agricultural and Nutritional Sciences

25 Preventive Nutrition Group

26 Martin Luther University Halle Wittenberg, Von-Danckelmann-Platz 2

27 D-06120 Halle/Saale (Germany

28 Phone: $0345-5522724$

29 Email: andreas.mueller@landw.uni-halle.de 
36

37

38

39

40

41

42

43

44

45

46

47

48

49

50

51

52

53

54

55

56

57

58

59

60

61

62

63

64

65

66

67

68

69

70

71

72

73

74

75

76

77

78

79

80

\section{SYNOPSIS}

Sodium selenite and sodium selenate are approved inorganic Se compounds in human and animal nutrition serving as precursors for selenoprotein synthesis. In recent years numerous additional biological effects over and above their functions in selenoproteins have been reported. For greater insight into these effects our study examined the influence of selenite and selenate on the differential expression of genes encoding non-selenoproteins in the rat liver using microarray technology. 5 groups of 9 growing male rats were fed a Se deficient diet or diets supplemented with 0.20 or $1.0 \mathrm{mg} \mathrm{Se} / \mathrm{kg}$ as sodium selenite or sodium selenate for 8 weeks. Genes which were more than 2.5 -fold up- or down-regulated by selenite or selenate compared to Se deficiency were selected. Glutathione peroxidase 1 was upregulated 5.5 -fold by both Se compounds, whereas glutathione peroxidase 4 was upregulated only 1.4-fold. Selenite and selenate down-regulated three phase II enzymes. Despite the regulation of many other genes in an analogous manner, frequently only selenate changed the expression of these genes significantly. In particular, genes involved in the regulation of the cell cycle, apoptosis, intermediary metabolism, and those involved in Se deficiency disorders were more strongly influenced by selenate. The comparison of seleniteand selenate-regulated genes revealed that selenate may have additional functions in the protection of the liver, and that it may be more active in metabolic regulation. In our opinion the more pronounced influence of selenate compared to selenite on differential gene expression results from fundamental differences in the metabolism of these two Se compounds.

Keywords: Selenium, selenite, selenate, differential gene expression, microarray rat

(1)




\section{INTRODUCTION}

82 Since the discovery of the essentiality of selenium (Se) five decades ago, this element has

83

84

85

86

87

88

89

90

91

92

93

94

95

96

97

98

99

100

101

102

103

104

105

106

107

108

109

110

111

112

113

114

115

116

117

118

119

120

121

122

123

124

125

126

127

128

129

130

131

132

133

134 been increasingly associated with many biological processes [1]. In contrast to other metal trace elements which interact with proteins as cofactors, the physiological functions of Se derive mainly from the incorporation of $\mathrm{Se}$ into the active sites of functional selenoproteins via the cotranslational synthesis of selenocysteine [1]. To date the existence of not less than 33 functional selenoproteins with at least one selenocysteine residue has been reported. The best investigated characteristic of $\mathrm{Se}$ is its antioxidant role. Six different glutathione peroxidases (GPx1 - GPx6) and two thioredoxin reductases (TrxR 1 and TrxR2) contribute largely to the maintenance of cellular antioxidant defense. The involvement in thyroid metabolism through iodothyronin deiodinase activity represents a further important Se dependent target [2]. Under conditions of low Se availability, these selenoproteins selectively are down-regulated. Whereas GPx1, exhibiting a high and ubiquitous expression and activity in mammalian tissues, and plasma glutathione peroxidase (GPx3) undergo a rapid and severe down-regulation, gastrointestinal glutathione peroxidase (GPX2) and phospholipidhydroperoxide glutathione peroxidase (GPx4) are far more conserved [3, 4]. Depending on the animal species, a long term Se deficiency causes liver necrosis and myopathies [5-8]. Besides the mechanisms of functional selenoproteins, in recent years additional information on Se biochemistry has been obtained. The down-regulation of phase II detoxification enzymes such as glutathione-S-transferases and aflatoxin b1 aldehyde reductase (Afar) due to adequate Se supply impressively shows the counter regulation of cellular stress response [9, 10]. Anti-carcinogenic effects of supranutritive Se dosages, investigated in animal trials and tissue culture experiments, may result from the initiation of proapoptotic mechanisms by the generation of monomethylselenol and high concentrations of reactive oxygen species [11], or from the response of phosphorylation- and signal transduction mechanisms [12]. Other hypotheses suggest the reversion of the hypermethylated DNA of tumour suppressor genes [13] or the reduction of prostaglandin E2 and cyclooxygenase 2 via GPx2 activity as being the underlying mechanisms for the protective effect of Se against colon cancer [14]. However, the results of large placebo controlled human intervention trials did not support uniquely beneficial effects of supranutritional Se supplementation in the prevention of several cancers $[15,16]$. The influence of Se supplementation and selenoprotein activities on obesity, insulin resistance, diabetes and hyperlipidaemia has been the subject of recent controversial discussion. Whereas only very high supranutritive selenate doses have antidiabetic effects [17], a high activity of GPx1 as well as a high Se status derived from the permanent intake of Se supplements have lately been reported as being one possible cause of the accelerated development of obesity, insulin resistance, diabetes and hyperlipidaemia [18-22]. These important results were the outcome of the above mentioned cancer intervention trials and of large cross sectional studies [15, 19-21]. Optimum activities of all functional selenoproteins can be obtained by a daily Se uptake of $30-70 \mu \mathrm{g}$ in humans and by a concentration of $0.15-$ $0.30 \mathrm{mg} \mathrm{Se} / \mathrm{kg}$ diet in animals. The inorganic Se compounds sodium selenite (+IV) and sodium selenate $(+V I)$ are approved Se additives both in human mineral supplements and in animal feed. Both selenite and selenate have a high absorption rate from the small intestine [23], but they exhibit some fundamental differences in their absorption mechanism as well as in their intermediary metabolism. There is no doubt that selenite and selenate represent valuable inorganic Se compounds to ensure adequate selenoprotein synthesis [24, 25]. Nevertheless, information is lacking whether and in what way selenite and selenate influence the expression of genes beyond functional selenoproteins. In this context the present study using microarray analysis (MA) as the analytical tool had the following aims:

- Data mining of genes regulated differentially by selenite or selenate supplementation versus a control group with Se deficiency.

- $\quad$ Exploring genes responding in particular to selenite or selenate supplementation by direct comparison of the selenite and selenate expression profile. 
135 A nutrition trial with healthy growing rats served as the basis for the examination of

136

137

138

139

140

141

142

143

144

145

146

147

148

149

150

151

152

153

154

155

156

157

158

159

160

161

162

163

164

165

166

167

168

169

170

171

172

173

174

175

176

177

178

179

180

181

182

183

184

185

186

187

188

differential gene expression by selenite and selenate.

\section{MATERIALS AND METHODS \\ Rats and diet preparation}

45 weanling albino rats (HK 51, strain of the Institute of Animal Nutrition and Nutritional Physiology) were randomly assigned to 5 groups of 9 . The average initial body weight (62.8 $\pm 4.0 \mathrm{~g}$ ) did not vary among groups. The rats were fed a Torula yeast based diet as described earlier [30] for 8 weeks. The diet was composed according to the current recommendations of the National Research Council (NRC) [26] with the exception of Se. The analyzed Se concentration of the basal diet (group 0) was below the detection limit $(<0.03$ $\mathrm{mg} \mathrm{Se} / \mathrm{kg}$ diet). Groups I and II were fed diets adequate in Se $(0.20 \mathrm{mg} \mathrm{Se} / \mathrm{kg}$ diet $)$ either supplemented with sodium selenite (group I) or sodium selenate (group II). The diets of groups III and IV were supplemented with sodium selenite or sodium selenate to a supranutritive Se concentration of $1.0 \mathrm{mg} \mathrm{Se} / \mathrm{kg}$ diet. The rats were kept individually in plastic cages with wood shavings as bedding under standard laboratory conditions $\left(22^{\circ} \mathrm{C}, 55 \%\right.$ humidity, $12 \mathrm{~h}$ light : dark cycle) and had free access to the diet and deionized water. The protocol of the animal experiment was approved by the Regional Council of Giessen and by the animal welfare committee of Giessen University. At the end of the trial, the rats were anaesthetized in a carbon dioxide atmosphere and subsequently decapitated. The liver was removed, frozen in liquid nitrogen, and stored at $-80^{\circ} \mathrm{C}$ until analysis.

\section{Se analysis in diets and liver}

Se concentration in the diets and the livers was determined by hydride generation atomic absorption spectrometry (AAS, Unicam PU 9400 X; PU 3960 X) as reported previously [27]. Certified samples from the National Institute of Standard and Technology (soft winter wheat flour, NIST No. 8438 and bovine liver, NIST No. 1577 b) served as reference material for Se determination in the different matrices.

\section{RNA extraction and microarray analysis}

The analysis of differentially expressed genes was performed using "10k rat oligoarrays" from MWG (Ebersberg, Germany). On one single MA slide, short nucleotide sequences of 9,715 different rat genes are spotted in duplicate, which allows the co-hybridisation of RNA samples from 2 experimental groups on one MA slide. RNA was extracted from the liver of 5 rats per group by the phenol chloroform guanidine thiocyanate extraction protocol [28], further purified by a DNAse 1 digest and pooled. Direct Cy3 or Cy5 labeling of single stranded DNA by synthesis from $100 \mu \mathrm{g}$ total RNA, MA hybridization- and scanning, background correction, and data analysis up to comparable expression values were performed by MWGBIOTECH AG, Ebersberg, Germany (http://www.mwg-biotech.com/). The samples were assigned to the 6 microarrays as follows:

Microarray 1: Cy3 (group 0), Cy5 (group I); Microarray 2: Cy3 (group 0), Cy5 (group II); Microarray 3: Cy3 (group 0), Cy5 (group III); Microarray 4: Cy3 (group 0), Cy5 (group IV); Microarray 5: Cy3 (group I), Cy5 (group II); Microarray 6: Cy3 (group III), Cy5 (group IV).

For the comparison of the expression data from selenite and selenate treated rats with that of their companions on Se deficiency the following criteria were applied:

- Only genes with average Cy3 and Cy5 values that were 2-fold above the background were used.

- Only genes that were at least 2.5-fold up- or down-regulated by selenite or selenate treatment were considered.

- Only genes regulated in an analogous manner by selenite and selenate were considered.

- Only genes which fulfilled the statistical assumptions were considered (c.f. statistical analysis).

Differentially expressed genes were assigned to 5 functional areas and are shown in Table 1. 
189 Area I: $\quad$ Genes involved in phase I and phase II detoxification

Area II:

191

192

193

194

195

196

197

198

199

200

201

202

203

Area III:

Area IV: Genes involved in the regulation of intermediary metabolism and in the regulation of appetite, body weight or other metabolic processes

Area $\mathrm{V}$ : Genes related to the cell cycle, cell development, cell death (apoptosis) or tumour metabolism Area $V$ : Genes related to inflammatory or immunomodulatory response In addition to the examination of the influence of selenite and selenate on differential gene expression versus Se deficiency a direct comparison of selenite- and selenate-regulated gene expression was carried out.

Validation of the MA data for selected differentially expressed genes (GPx1, GPx4, GSTa2, PTP1B) by two step reverse transcriptase PCR (2-step RT-PCR)

For GPx1, GPx4, GSTa2 and PTP1B the validation of the MA data was carried out using 2step reverse transcriptase PCR (2-step RT-PCR). The expression data were normalized to $\beta$ actin expression. The 2-step RT-PCR method applied was elaborated and refined in our laboratory, and was described in detail previously [22]. New liver RNA pools were prepared for the RT-PCR experiments from the same 5 rats per group to exclude casual and systematic errors of the MA expression data. The gene bank accession numbers, the PCR primers used, and the length of the amplificates were as follows: Rat GPx1: NM 030826, primer forward: TCA TTG AGA ATG TCG CGT CT, primer reverse: CCC ACC AGG AAC TTC TCA AA, amplificate length: $388 \mathrm{bp}$; Rat GPx4: NM: 017165, primer forward: ATG CAC GAA TTC TCA GCC AAG, primer reverse: GGC AGG TCC TTC TCT AT, amplificate length: 461 bp; Rat GSTa2: NM 0170131, primer forward: CAG GAG TGG AGT TTG ATG AGA, primer reverse: AGA GGG AAA GAG GTC AGA AG, amplificate length: 463 bp; Rat PTP1B: NM 012637, primer forward: GCA CTT CTG GGA GAT GGT GT, primer reverse: AAG AGG AAA GAC CCG TCC TC, amplificate length: 449; Rat $\beta$ actin: NM 0311441, primer forward: TGT TAC CAA CTG GGA CGA CA, primer reverse: TCT CAG CTG TGG TGG TGA AG, amplificate length: $396 \mathrm{bp}$.

\section{Determination of GPX1 and GPX4 activity}

The activities of GPx1 and GPx4 were determined spectrophotometrically (Beckmann DU 50) recording glutathione dependent peroxide reduction coupled to glutathione reductase and NADPH oxidation at $340 \mathrm{~nm}$ [29]. For GPx1 activity, the diluted cytosolic supernatants of rat liver homogenates served as sample material. For GPx4 activity, crude homogenates of livers were prepared in a sucrose buffer [30]. $\mathrm{H}_{2} \mathrm{O}_{2}$ served as the substrate for GPx1 determination, whereas freshly synthesized phosphatidylcholine hydroperoxide (PCOOH) was used for measurement of GPx4 activity [30]. One unit of GPx1 and GPx4 activity was defined as one micromole NADPH oxidized/min and normalized to $1 \mathrm{mg}$ protein.

\section{Activity of the phase II detoxification enzymes GSTa2 and epoxide hydrolase}

The activity of alpha glutathione-S-transferases to which GSTa2 activity makes a large contribution was selectively determined according to a spectrophotometric protocol using the specific substrate 7-chloro-4-nitrobenzoic-2-oxa-1,3-diazole (NBD-Cl) [31]. The increase in absorption at $419 \mathrm{~nm}$ caused by the conjugation of NBD-Cl to 7-glutathionyl-4-nitrobenzoic2-oxa-1,3-diazole (NBD-GSH) was recorded for $3 \mathrm{~min}$. $1 \mathrm{U}$ of alpha glutathione-S-transferase activity was defined as the formation of $1 \mu \mathrm{mol}$ of $\mathrm{NBD}-\mathrm{GSH} / \mathrm{min}$ and normalized to $1 \mathrm{mg}$ protein.

Epoxide hydrolase activity in 1:5 (w/v) crude liver homogenates was measured according to a spectrophotometric protocol using styrene oxide as the substrate [42]. In the first reaction step, $45 \mu \mathrm{L}$ of the liver homogenates were incubated in $630 \mu \mathrm{L}$ of $50 \mathrm{mM}$ phosphate buffer containing $10 \% \mathrm{DMSO}$ and $10 \mathrm{mmol} / \mathrm{L}$ of the substrate styrene oxide for $2 \mathrm{~h}$ at $36^{\circ} \mathrm{C}$. This reaction step allows the formation of the vicinal diol from the epoxide by the activity of epoxide hydrolase. Subsequently the samples were treated with $200 \mu \mathrm{L} 100 \mathrm{mM}$ sodium periodate and $135 \mu \mathrm{L} 0.8 \mathrm{M}$ sodium sulphite in order to oxidize the vicinal diol to the 
245

246

247

248

249

250

251

252

253

254

255

256

257

258

259

260

261

262

263

264

265

266

267

268

269

270

271

272

273

274

275

276

277

278

279

280

281

282

283

284

285

286

287

288

289

290

291

292

293

294

295

296

297

298

299

300

corresponding aldehyde and to reduce excess sodium periodate to sodium iodide. $500 \mu \mathrm{L}$ supernatant of this reaction were incubated at $70^{\circ} \mathrm{C}$ with $50 \mu \mathrm{L}$ Schiffs reagent to form a red magenta dye. The extinction was read in a spectrophotometer at $560 \mathrm{~nm}$ and compared with a calibration curve prepared with 1-phenyl-1,2-ethanediol. $1 \mathrm{U}$ of epoxide hydrolase was defined as the formation of $1 \mu \mathrm{mol}$ vicinal diol/min and related to $1 \mathrm{mg}$ protein.

\section{Statistical analysis}

Data are given as means \pm standard deviation. For the enzymatic analyses and for the RTPCR data, statistical differences between means $(P<0.05)$ were analysed with "SPSS 14.0 for Windows" by one way ANOVA after ascertaining the normality of distribution (Shapiro Wilk test and Kolmogorov Smirnov test) and homogeneous variances (Levene test). Differences between means were analyzed with the LSD test if variances were homogeneous or with the Games Howell test if not. Changes in gene expression (MA data) were analyzed with Student's t test. At $\mathrm{P}<0.05$, expression differences were accepted as statistically significant if homogeneous variances and the normality of distribution could be ensured. In order to reduce the genes differentially expressed among treatment groups to a manageable number for publication only genes which were at least 2.5-fold up-or downregulated by selenite or selenate treatment were considered (Table 1). Only genes which were regulated in an analogous manner by selenate at both dietary concentrations or in addition by selenite at one dietary concentration are displayed.

\section{RESULTS}

\section{Effect of Se status on feed intake and live weight}

After 8 weeks no significant differences in feed intake and live weight (final average weight $285.8 \pm 7.0 \mathrm{~g}$ ) were observed between rats receiving a Se deficient diet (0) compared to their littermates with Se adequate nutrition (I, II) or supranutritive Se supply (III, IV).

\section{Concentration of Se in diets and liver}

The basal diet based on Torula yeast was readily accepted by the rats and exhibited a Se concentration below the detection limit $(<0.03 \mathrm{mg} / \mathrm{kg})$. Analyzed Se levels of the supplemented diets corresponded well with the values scheduled in the experimental design (I: $0.21 \pm 0.009 \mathrm{mg} / \mathrm{kg}$ fresh matter ( 90\% dry matter), II: $0.19 \pm 0.010$, III $0.96 \pm 0.071$, $0.85 \pm 0.025)$. Liver Se concentration in group $0(21.2 \pm 2.40 \mu \mathrm{g} / \mathrm{kg}$ fresh matter) decreased to $2 \%$ of that of rats with adequate Se intake (I: $1044 \pm 88.6$, II: $1050 \pm 78.4$ ). Supranutritive Se (III: 2233 \pm 197 , IV: $2148 \pm 149$ ) again increased liver Se concentration significantly compared to groups I and II. At both dietary levels no significant differences existed between selenite and selenate regarding their efficacy in influencing liver Se concentration.

\section{GPx1- and GPx4 activity and expression}

As a sensitive parameter of Se deficiency, GPx1 expression and activity were significantly decreased in the Se deficient group 0. (Figure $1 \mathrm{~A}, \mathrm{C}$ ). Independent of the Se compound, the supplementation with $0.2 \mathrm{mg} \mathrm{Se} / \mathrm{kg}$ diet (groups I and II) resulted in a strong increase in GPx1 activity (73-fold) which was accompanied by multiplied gene expression in the MA experiment ( 7.5 -fold). MA data also indicated a marked increase in GPx1 expression ( 6.0fold) for groups III and IV which received diets with supranutritive Se $(1.0 \mathrm{mg} \mathrm{Se} / \mathrm{kg}$ ) compared to group 0 (Figure $1 \mathrm{~A}$ ). GPx1 activity did not quite reach the level of the adequately supplemented groups (Figure $1 \mathrm{C}$ ). The differences in GPx1 mRNA expression, as indicated by the MA data, could be confirmed by 2-step RT-PCR analysis (Figure 1 A). In contrast only a non significant weak influence of varying Se supplementation on gene expression of GPx4 was measured. GPx4 responded to Se deficiency only by a non significant minor down-regulation of its mRNA (1.2 to 1.6-fold) and by a 1.5 to 2.0 -fold loss of activity (Figure $1 \mathrm{~B}, \mathrm{C}$ ). The mRNA expression data obtained by MA analysis could be confirmed by 2-step RT-PCR analysis. No influence of the supplemented Se compound (selenite or selenate) and of the dietary Se level $(0.2$ and $1.0 \mathrm{mg} / \mathrm{kg})$ on GPx4 expression and activity could be observed. 
301 General results for differential gene expression with regard to the comparison of

302

303

304

305

306

307

308

309

310

311

312

313

314

315

316

317

318

319

320

321

322

323

324

325

326

327

328

329

330

331

332

333

334

335

336

337

338

339

340

341

342

343

344

345

346

347

348

349

350

351

352

353

354

355

\section{selenite- or selenate feeding versus Se deficiency}

Despite no differences between selenite and selenate in the regulation of the selenoproteins GPx1 and GPx4, the most challenging and unexpected finding in our study was the fact that compared to Se deficiency (group 0) both dietary selenate levels (groups II and IV) had a distinctly stronger influence on differential gene expression than selenite (groups I and III).

Thus with a ratio of 2.5 compared to Se deficiency about 300 genes were significantly regulated by selenate feeding, whereas selenite only affected the expression of 43 and 44 genes, respectively. For both inorganic Se compounds the comparison of the nutritional level $(0.2 \mathrm{mg} / \mathrm{kg})$ and the supranutritive level $(1.0 \mathrm{mg} / \mathrm{kg})$ revealed no significant differences in the total number of up-or down-regulated genes.

Specific results for differential gene expression with regard to the comparison of selenite- or selenate feeding versus Se deficiency after mapping functional areas

After analysis of the general effects of selenite and selenate on differential gene expression we mapped genes which were up- or down-regulated in an analogous manner compared to Se deficiency at least by selenate feeding ( 242 genes) into 5 functional areas (c.f. Material and Methods). The results of this mapping are shown in Table 1 for 44 representative genes. By displaying the regulation ratio as well as the significance level also for the selenite groups I and III, Table 1 clearly shows that selenate feeding (groups II and IV) compared to Se deficiency (group 0) influences the differential expression of genes in all functional areas investigated much more distinctly and significantly than selenite feeding. To confirm the results of the MA analysis we validated the expression data for 3 representative target genes (GST2a, area I; epoxide hydrolase, area I; PTP1B, area II) by 2-step RT-PCR and/or enzymatic analysis in addition to GPx1- and GPx4-expression. One very challenging result of our study was the fact that Se strongly influences the regulation of phase I- and phase IIdetoxification genes (Table 1, area I). Three mRNAs of phase II-detoxifying enzymes, namely Aflatoxin B1 aldehyde reductase (Afar), Alpha glutathione-S-transferase (GSTA2) and Epoxide hydrolase were distinctly down-regulated by Se feeding (groups I, II, III, and IV) compared to Se deficiency (group 0). For these enzymes, selenite feeding was also effective at both dietary levels. We could confirm the validity of the MA data by measurement of GSTA2 expression and activity (Figure $2 \mathrm{~A}$ and B) and Epoxide hydrolase activity Figure 2 C). Contrary to the down-regulation of phase II-detoxifying enzymes, the phase Ihaemoprotein cytochrome p450c was up-regulated by selenate.

In particular by selenate feeding, numerous genes controlling intermediary nutrient metabolism, the regulation of appetite and body weight and other metabolic processes (Table 1, area II) were differentially regulated compared to Se deficiency. Although selenite feeding influenced the expression of these genes into the same direction, the strength of regulation was not significant in most cases. In the case of Heme oxygenase 3 and Transferrin receptor, two genes of iron metabolism were distinctly affected in their expression by selenate feeding. The distinct up-regulation of Agouti related protein precursor, Hypocretin orexin receptor 1 , Neuropeptide y precursor, and Ob-receptor gene related protein suggests the involvement of Se in central processes of appetite- and body weight-regulation. Moreover a distinct influence of Se on carbohydrate- and lipid metabolism was indicated by the regulation of Acyl-coenzyme A:cholesterol acyltransferase 1, Fructose-6-phosphate-2kinase, and Phosphorylase-b-kinase. A strong influence of selenate was also observed for the regulation of genes involved in metabolic signal transduction pathways (80-k diacylglycerol kinase, and Protein tyrosine phosphatase 1B), the regulation of vascular tone (Arginase II) and even in folate metabolism (Gamma glutamyl hydrolase precursor). In area II the validity of the MA data was confirmed by the examination of the expression and the activity of the insulin antagonistic PTP1B (Figure 3). Thus Se feeding with both selenite and selenate led to a 1.7 to 2.8 -fold up-regulation of PTP1B mRNA, accompanied by a $\sim 3.0$-fold increase in enzyme activity (Figure 3).

In area III (Table 1) a number of apoptosis promoting genes such as BCL2-antagonist, Dermatan sulfate proteoglycan II, FOS related antigen, Mast cell protease 1, p58, and 
356 Rapamycin- and FKBP 12 target 1 were distinctly up-regulated by selenate. p58 was also

357

358

359

360

361

362

363

364

365

366

367

368

369

370

371

372

373

374

375

376

377

378

379

380

381

382

383

384

385

386

387

388

389

390

391

392

393

394

395

396

397

398

399

400

401

402

403

404

405

406

407

408

409

410

411 strongly affected by selenite feeding.

In contrast, other regulated genes in area III (NAPOR-3, Granzyme k) indicated an antiapoptotic role of Se. Moreover, in area III the regulation of genes participating in growth and differentiation of various tumours (ADAMTS-1, PKCQ interacting protein picot, and Proliferin related protein) indicate a tumour-protective function of Se. The differential regulation of numerous genes related to inflammatory or immunomodulatory reactions (area IV) as well as of genes with other functions, such as structural protein function, hormonal function, receptor function, a function in signal transduction or a function as an ion channel (area V) clearly indicated biological functions of $\mathrm{Se}$ beyond its role in functional selenoproteins. Whereas the regulated genes of area IV indicate an important target function of $\mathrm{Se}$ in the modulation of immune response, numerous regulated genes of area $\mathrm{V}$ may give some new insight into the beneficial effects of Se in the prevention of Se deficiency diseases, such as muscular dystrophy and liver necrosis. Differentially expressed genes indicating such a response are e.g., Calcium transporting ATPase Serca 1a, Cardiac ankyrin repeat protein, Mu-calpain large subunit, Tissue inhibitor of metalloproteinase 3, Titin, and Cyclic3',5'-monophosphate response element binding protein 1.

\section{Results for differential gene expression with regard to the direct comparison of selenite and selenate feeding}

At a ratio of $2.5(\mathrm{P}<0.05)$ a total number of 18 genes ( 3 down-regulated and 15 up-regulated) were found as being differentially expressed by selenate and selenite feeding. Table 2 shows a selection of 11 differentially expressed genes from this comparison. As can be seen from Table 2 the final ratios originate from different regulatory effects (for details see table legend).

The regulation of the 5-hydroxytryptamine serotonin receptor 6 and the Growth hormonereleasing hormone receptor beta indicates a more pronounced influence of selenate in liver fatty acid- and sterol metabolism as well as in central mechanisms of body weight regulation compared to selenite. The Alphab crystalline-related protein (Heat shock protein 20) and its precursor the golgi associated protein Gcp 360 which are down-regulated during the development of hepatocellular carcinoma showed a higher expression due to selenate feeding. Both genes were also found as being more highly expressed by selenate in the expression profile versus Se deficiency (c.f. Table 1). The differential regulation of Ly-49.9 antigen and the inhibitory natural killer cell receptor Nkr-p1b point to a higher influence of selenate in modulating $T$ cell response compared to selenite. The Aldo-keto reductase akr1b7 which was up-regulated by selenate compared to selenite plays an important role in lipid detoxification, in particular in the small intestine. Titin which increases the elasticity of cardiomyocytes showed a significantly up-regulation due to selenate feeding. Titin was also found as being more highly expressed by selenate in the expression profile versus $\mathrm{Se}$ deficiency (c.f. Table 1).

Additional information on functions of the regulated genes in Table 1 and on other selected genes of the functional areas I to $\mathrm{V}$ are shown in Tables 1 to 5 as online supporting material. Moreover the full microarray data sets are available as online supporting material. The assignment of the samples to the 6 microarrays can be seen from the first sheet in the Excel file containing the data of the microarrays 1 to 3 . The second Excel file contains the original data of the microarrays 4 to 6 . The red marked columns $I$ and $L$ are the backgroundcorrected expression data for the single genes which can be used to compare gene expression.

\section{DISCUSSION}

In recent years specific knowledge of the biological effects of Se beyond its role in functional selenoproteins has advanced. Both positive and critical functions of Se with regard to diseases of the Western World such as cancer, cardiac diseases, obesity, insulin resistance, diabetes and hyperlipidaemia have been investigated. To obtain information on cellular mechanisms underlying such specific biological effects of Se we used MA scanning as the 
412 analytical tool. Moreover, we examined the effectiveness of the two inorganic

413

414

415

416

417

418

419

420

421

422

423

424

425

426

427

428

429

430

431

432

433

434

435

436

437

438

439

440

441

442

443

444

445

446

447

448

449

450

451

452

453

454

455

456

457

458

459

460

461

462

463

464

465

466

467 selenocompounds selenite (Se oxidation state $+\mathrm{IV}$ ) and selenate (Se oxidation state $+\mathrm{VI}$ ) for differential gene expression. In order to produce as distinct effects for Se as possible, we compared the gene expression of Se supplemented rats with that of their companions during Se deficiency. In addition a direct comparison of selenite- and selenate-regulated genes was carried out. With regard to the regulation of functional selenoproteins our data (Table 3 ) are in accordance with very recent findings on the influence of Se status on selenoprotein mRNA levels in mice and rats [33].

The pronounced loss of GPx1 mRNA expression and activity due to Se deficiency and a maximization of both parameters by Se supply at the recommended dietary level $(0.2 \mathrm{mg}$ $\mathrm{Se} / \mathrm{kg}$ as selenite or selenate, groups I and II) and at a moderate supranutritive supply (1.0 $\mathrm{mg} \mathrm{Se} / \mathrm{kg}$ as selenite or selenate) confirm the low rank of GPx1 in the hierarchy of selenoproteins. Conversely the high rank of GPx4 was confirmed by only a small loss of mRNA expression and enzyme activity as well as a low $P$ value for regulation (Table 3 ) due to a lack in dietary Se supply. Our results moreover suggest that selenite and selenate are similar in their effectiveness in influencing the expression and activity of GPx1, GPx4 and the expression of further selenoproteins.

The counter-regulation of GPx1 and the phase II detoxification enzymes GSTa2, epoxide hydrolase and Afar (Table 1, area I) was another central finding of our study. In the literature a few reports describe similar effects of $\mathrm{Se}$ on these so called xenobiotica metabolizing enzymes. Thus in a rat trial an increased aflatoxin toxicity due to Se supplementation was observed, while a moderate Se deficiency effected a distinctly better aflatoxin detoxification based on the up-regulation of the assigned Aflatoxin-B1-aldehyde reductase (Afar) and additionally of GSTA2 [9]. Other studies reported an up-regulation of several glutathione-Stransferases and of Epoxide hydrolase in rat liver by Se deficiency. However, recent consolidated findings have shown the underlying mechanism for this phenomenon. In Se deficiency, the transcription of phase II detoxification enzymes increases via the activation of the Antioxidant Response Element (ARE), a DNA structure located upstream the coding DNA sequence of these enzymes. ARE activation is sensitive to changes in cellular redox status, an increase in peroxide tone, and to interaction with the transcription factor NF-E2related factor 2 (Nrf2). Different glutathione-S-transferases, various aldo-keto-reductases, such as Afar, and epoxide hydrolases possess an ARE. In our study the up-regulation of phase II detoxification enzymes by Se deficiency and vice versa the down-regulation with sufficient Se supply were supported by Heme oxygenase 3 regulation, representing another enzyme with an ARE in its DNA. That heme oxygenases respond to Se status is confirmed by the results of other trials, in which an up-regulation of heme oxygenase 1 due to a lack of Se supply was reported [10].

However, a very important and unexpected result of our study was the finding that selenate feeding related to Se deficiency had a distinctly stronger influence on differential gene expression than selenite.

Fundamental differences in the intestinal absorption pathways, in the blood transport to peripheral organs, and in the subsequent intermediary metabolism of selenite (Se oxidation state $+\mathrm{IV}$ ) and selenate (Se oxidation state $+\mathrm{VI}$ ) may provide one plausible explanation for this effect $[23,34]$. In peripheral organs the absorption products from dietary selenite (oxidation states 0 and $-\mathrm{I}$ ) need far fewer reduction steps than selenate (oxidation state $+\mathrm{VI}$ ). In Figure $4 \mathrm{~A}, \mathrm{~B}$ and $\mathrm{C}$ possible chemical reactions of selenite and selenate are summarized $[17,35,36]$ which may explain the increased thiol reactivity of dietary selenate in peripheral tissues and represent one essential reason for its greater potential in influencing differential gene expression. The metabolic fates of different Se compounds still need intensive investigation using Se species analysis and protein mass spectrometry. Antidiabetic and insulin sensitizing effects of Se, restricted exclusively to the intermittent application of very high selenate doses, are based on the inhibition of Protein tyrosine phosphatase $1 \mathrm{~B}$ (PTP1B). According to Figure $4 \mathrm{~B}$ and $\mathrm{C}$ selenious acid formation and superoxide anion generation during the peripheral reduction of larger selenate quantities provide a good example of the high reactivity of oral selenate towards cysteine residues in proteins such as PTP1B. For the interpretation of future data from Se studies, one should consider that orally 
468

469

470

471

472

473

474

475

476

477

478

479

480

481

482

483

484

485

486

487

488

489

490

491

492

493

494

495

496

497

498

499

500

501

502

503

504

505

506

507

508

509

510

511

512

513

514

515

516

517

518

519

520

521

522

applied selenate mimics properties of selenite applied in cell cultures and in other in vitro studies $[11,17,23]$.

In our present MA experiment we have analyzed a distinct up-regulation of PTP1B mRNA due to Se supplementation at the recommended dietary level and at a slightly supranutritive concentration. PTP1B has recently been discussed as being a promising target in the treatment of obesity, insulin resistance and diabetes. Moreover, the enzyme is involved in growth and development of mammary tumours and in the activation of lipogenesis. Via the reduction of tyrosine phosphorylation of key signalling proteins such as IRS1 and Akt, an increased expression and activity of PTP1B may force the development of insulin resistance, obesity, hyperlipidemia, and diabetes [37, 38]. It may also be critical with regard to the growth of mammary cancer [39]. In contrast the reduced Akt phosphorylation mediated by increased PTP1B activity through dietary Se supplementation has been investigated as one mechanism explaining possible beneficial Se effects in prostate cancer treatment [12]. With regard to metabolic disorders recent large cross sectional studies and Se intervention trials support the PTP1B hypothesis by the finding that a significant positive correlation exists between Se status and the incidence of type II diabetes and increased blood lipids [15, 1921]. In this context the detailed regulation of PTP1B by dietary Se has recently been investigated by our group [22].

The regulation of other genes by selenate feeding (Table 1, area II) in particular indicates additional pathways by which Se may promote the development of insulin resistance, obesity, hyperlipidaemia and diabetes beside PTP1B regulation. Both the down-regulation of 80-k diacylglycerolkinase and the up-regulation of the Agouti related protein precursor, the Hypocretin orexin receptor and of the Neuropeptide y precursor open perspectives for future research concerning the role of Se in metabolic diseases [15, 18-21].

As mentioned above our data for the comparison of Se supplementation versus Se deficiency suggest a possible preventive mechanism of Se with regard to prostate cancer. Similarly the regulation of genes involved in growth and differentiation of mammary cancer and lung cancer (ADAMTS-1), of colorectal cancer (PKCQ-interacting protein Picot), as well as of various cancer types (Proliferin related protein) indicated a cancer protective function of Se (Table 1, area III) [40-42]. However these effects did not increase by increasing Se supplementation from the recommended dietary amount to the supranutritive level. The comparison of selenite- and selenate-regulated genes indicated a possible additional role of selenate with regard to the prevention of hepatocellular cancer (Alphab crystalline-related protein $=$ heat shock protein 20 , Table 2) [43].

Large human intervention trials carried out to investigate the preventive role of long term Se supplement use in cancer prevention revealed inconsistent results. Thus in the Nutritional Prevention of Cancer (NPC) study in which 1,312 high-risk dermatology patients received $200 \mu \mathrm{g} \mathrm{Se} /$ day in the form of selenized yeast or a placebo (matched control), a decreased risk of lung, colon, prostate, and total cancers was obtained by Se intervention, but an increased risk of nonmelanoma skin cancer. In a smaller subtrial of the NPC study in which the participants received even $400 \mu \mathrm{g}$ Se/day the cancer protective effect of the $200 \mu \mathrm{g}$ dose was lost [16]. In contrast the Selenium and Vitamin E Cancer Prevention Trial (SELECT) in which healthy men were supplemented either with $200 \mu \mathrm{g}$ Se/day in the form of selenomethionine or with vitamin E (400 I.U./day) or with a combination of both supplements compared to a placebo group was abandoned prematurely in autumn 2008 since the Se supplemented participants showed a $5 \%$ higher incidence of prostate cancer [15]. Due to the fact that tumour cells frequently possess a changed apoptosis program, the long term use of supranutritional Se supplements in cancer prevention and treatment should be reconsidered as well. This position is corroborated by our microarray data indicating both pro- and antiapoptotic features of Se by modulation of the expression of NAPOR 3, BCL2-antagonist 1, FOS related antigen, Granzyme k, Mast cell protease, and p58 (Table 1, area III) [44-49]. Very recent findings suggest that Se supplementation for cancer prevention is of particular interest for humans with selenoprotein $\mathrm{P}$ polymorphisms since this genetic constellation may reduce Se transfer to the peripheral organs and the subsequent sufficient synthesis of antioxidant selenoproteins [50]. 
From the comparison of gene expression related to Se deficiency, our data suggest that Se and, in particular, selenate is effective in influencing many other genes in the mammalian organism. Thus the regulation of genes that are also expressed in the liver and have specific functions for the integrity of the heart muscle and the skeletal muscle (e.g., Cardiac ankyrin repeat protein, Fibroblast Growth factor 13, Glial cell line-derived neurotrophic factor receptor beta, Mu-calpain large subunit, Tissue inhibitor of metalloproteinase 3, Titin, and Winglesstype MMTV integration site family) [51-56] may help to gain new insight into the beneficial effects of $\mathrm{Se}$ in the prevention of muscular dystrophy (Table 1, area V). Similarly, the established effectiveness of Se in preventing liver necrosis is supported by the up-regulation of Alpha $7 \mathrm{c}$ integrin, Mitogen activated protein kinase 12 ZPK, Plectin 1 (Table 1, area III) and of Cyclic-Adenosine-3',5'-monophosphate response element binding protein 1 (Table 1, area $\mathrm{V})$ [57-60].

The direct comparison of selenite- and selenate regulated genes revealed additional effects of selenate e.g. in liver fatty acid- and sterol metabolism and in central mechanisms of body weight regulation (5-hydroxytryptamine serotonin receptor 6 and growth hormone-releasing hormone receptor beta) [61], in the protection against hepatocellular carcinoma (Alphab crystalline-related protein=heat shock protein 20 ), in the modulation of $T$ cell response (Ly49.9 antigen and the inhibitory natural killer cell receptor $\mathrm{Nkr}-\mathrm{p} 1 \mathrm{~b}$ ), and in the protection against lipid toxicity (aldo-keto reductase akr1b-7) [43, 62]

542

543

544

545

546

547

548

549

550

551

552

553

554

555

556

In summary our study on the effects of the two common inorganic Se compounds selenite and selenate on the differential expression of genes other than selenoproteins showed the following:

- Compared to Se deficiency as a control, selenite (Se oxidation state +IV) and selenate (Se oxidation state +IV) resembled each other in their effectiveness for seleoprotein synthesis. Both Se compounds could be demonstrated to be equally effective in the down-regulation of not less than 3 enzymes of phase II detoxification and of a further gene with an ARE in its DNA (Afar, epoxide hydrolase, GSTa2, heme oxygenase 3). This result demonstrates mechanisms of counter-regulation of antioxidant enzymes.

- Compared to Se deficiency selenate has a distinctly stronger influence than selenite on differential gene expression in various functional areas. This distinct difference, so far unknown, may result from fundamental differences in the absorption and the intermediary metabolism of both Se compounds. This remarkable difference for both Se compounds should be considered in future investigations into Se biochemistry.

- The direct comparison of selenite- and selenate regulated genes revealed additional functions of selenate in liver fatty acid- and sterol metabolism and in central mechanisms of body weight regulation, in the protection against hepatocellular carcinoma, in the modulation of $\mathrm{T}$ cell response, and in the protection against lipid toxicity (aldo-keto reductase akr1b-7).

- In view of the distinct influence of Se on differential gene expression, our data could contribute to an improved understanding of mechanisms by which Se may influence diseases of the Western world. Other genes differentially regulated by selenate provided deeper insight into the beneficial effects of Se in preventing Se deficiency symptoms such as muscular dystrophy and liver necrosis.

We conclude that future studies on the pathways of Se in the treatment of diseases should consider the particular effects of the Se compound used, and that the compilation of comparative differential gene expression profiles for further selenium compounds would be of interest.

\section{REFERENCES}

1 Hesketh, J. (2008) Nutrigenomics and selenium: gene expression patterns, physiological targets, and genetics. Annu. Rev. Nutr. 28, 157-177 
2 Gromer, S., Eubel, J. K., Lee, B. L. and Jacob, J. (2005) Human selenoproteins at a glance. Cell. Mol. Life Sci. 62, 2414-2437

3 Wingler, K., Böcher, M., Flohé, L., Kollmus, H. and Brigelius-Flohé, R. (1999) mRNA stability and selenocysteine insertion sequence efficiency rank gastrointestinal glutathione peroxidase high in the hierarchy of selenoproteins. Eur. J. Biochem. 259, 149-157

4 Weiss Sachdev, S. and Sunde, R.A. (2001 Aug 1) Selenium regulation of transcript abundance and translational efficiency of glutathione peroxidase- 1 and -4 in rat liver. Biochem. J. 357, 851-858

5 Cooper, L.T., Rader, V. and Ralston, N.V. (2007) The roles of selenium and mercury in the pathogenesis of viral cardiomyopathy. Congest. Heart Fail. 13, 193-199

6 Rederstorff, M., Krol, A. and Lescure, A. (2006) Understanding the importance of selenium and selenoproteins in muscle function. Cell. Mol. Life Sci. 63, 52-59

$7 \quad$ Burk, R.F., Lawrence, R.A. and Lane, J.M. (1980) Liver necrosis and lipid peroxidation in the rat as the result of paraquat and diquat administration. Effect of selenium deficiency. J. Clin. Invest. 65, 1024-1031

8 Korpela, H. (1990) Hepatic selenium concentration in pigs with microangiopathy (mulberry heart disease)-an animal model for the study of oxidative damage. Int. J. Vitam. Nutr. Res. 60, 156-158

9 McLeod, R., Ellis, E.M., Arthur, J.R., Neal, G.E., Judah, D.J., Manson, M.M. and Hayes, J.D. (1997) Protection conferred by selenium deficiency against aflatoxin $B_{1}$ in the rat is associated with the hepatic expression of an aldo-keto reductase and a glutathione-Stransferase subunit that metabolize the mycotoxin. Cancer Res. 57, 4257-4266

10 Sengupta, A., Carlson, B.A., Weaver, J.A., Novoselov, S.V., Fomenko, D.E., Gladyshev, V.N. and Hatfield, D.L. (2008) A functional link between housekeeping selenoproteins and phase II enzymes. Biochem. J. 413, 151-161

11 Xiang, N., Zhao, R. and Zhong, W. (2009) Sodium selenite induces apoptosis by generation of superoxide via the mitochondrial-dependent pathway in human prostate cancer cells. Cancer Chemother. Pharmacol. 63, 351-362

$12 \mathrm{Wu}$, Y., Zu, K., Warren, M.A., Wallace, P.K. and Ip, C. (2006) Delineating the mechanism by which selenium deactivates Akt in prostate cancer cells. Mol. Cancer Ther. 5, 246-252

13 Xiang, N., Zhao, R., Song, G. and Zhong, W. (2008) Selenite Reactivates Silenced Genes by Modifying DNA Methylation and Histones in Prostate Cancer Cells. Carcinogenesis. 29, 2175-2181

14 Banning, A., Florian, S., Deubel, S., Thalmann, S., Müller-Schmehl, K., Jacobasch, G. and Brigelius-Flohé, R. (2008) GPx2 counteracts PGE2 production by dampening COX2 and mPGES-1 expression in human colon cancer cells. Antioxid. Redox Signal. 10, 1491-1500

15 Lippman, S.M., Klein, E.A., Goodman, P.J., Lucia, M.S., Thompson, I.M., Ford, L.G., Parnes, H.L., Minasian, L.M., Gaziano, J.M., Hartline, J.A., Parsons, J.K., Bearden, J.D. 3rd, Crawford, E.D., Goodman, G.E., Claudio, J., Winquist, E., Cook, E.D., Karp, D.D., Walther, P., Lieber, M.M., Kristal, A.R., Darke, A.K., Arnold, K.B., Ganz, P.A., Santella, R.M., Albanes, D., Taylor, P.R., Probstfield, J.L., Jagpal, T.J., Crowley, J.J., Meyskens, F.L. Jr, Baker, L.H., Coltman, C.A. Jr. (2009) Effect of selenium and vitamin E on risk of prostate cancer and other cancers: the Selenium and Vitamin E Cancer Prevention Trial (SELECT). JAMA 301, 39-51

16 Reid, M.E., Duffield-Lillico, A.J., Slate, E., Natarajan, N., Turnbull, B., Jacobs, E., Combs, G.F. Jr, Alberts, D.S., Clark, L.C., Marshall, J.R. (2008) The nutritional prevention of cancer: 400 mcg per day selenium treatment. Nutr. Cancer 60, 155-63

17 Mueller, A.S. and Pallauf, J. (2006) Compendium of the antidiabetic effects of supranutritional selenate doses. In vivo and in vitro investigations with type II diabetic $\mathrm{db} / \mathrm{db}$ mice. J. Nutr. Biochem. 17, 548-560

18 McClung, J.P., Roneker, C.A., Mu, W., Lisk, D.J., Langlais, P., Liu, F. and Lei, X.G. (2004) Development of insulin resistance and obesity in mice overexpressing cellular glutathione peroxidase. PNAS 101, 8852-8857 
19 Stranges, S., Marshall, J.R., Natarajan, R., Donahue, R.P., Trevisan, M., Combs, G.F., Cappuccio, F.P., Ceriello. A, and Reid, M.E. (2007) Effects of long-term selenium supplementation on the incidence of type 2 diabetes. Ann. Intern. Med. 147, 217-223

20 Bleys, J., Navas-Acien, A. and Guallar, E. (2007 Apr) Serum selenium and diabetes in U.S. adults. Diabetes Care. 30, 829-834

21 Bleys, J., Navas-Acien, A., Stranges, S., Menke, A., Miller, E.R. $3^{\text {rd }}$ and Guallar, E. (2008) Serum selenium and serum lipids in US adults. Am. J. Clin. Nutr. 88, 416-423

22 Mueller, A.S., Bosse, A.C., Most, E., Klomann, S.D., Schneider, S. and Paliauf, J. Regulation of the insulin antagonistic protein tyrosine phosphatase 1B by dietary Se studied in growing rats. J. Nutr. Biochem. 20, 235-247

23 Vendeland, S.C., Butler, J. A. and Whanger, P.D. (1992) Intestinal absorption of selenite, selenate, and selenomethionine in the rat. J. Nutr. Biochem. 3, 359-365

24 Shigeta, K., Matsumura, K., Suzuki, Y., Shinohara, A. and Furuta, N. (2008) Distribution and dynamic pathway of selenium species in selenium-deficient mice injected with (82) Se-enriched selenite. Anal. Sci. 24, 1117-1122

25 Ravn-Haren, G., Bügel, S., Krath, B. N., Hoac, T., Stagsted, J., Jørgensen, K., Bresson, J. R., Larsen, E. H. and Dragsted, L. O. (2008) A short-term intervention trial with selenate, selenium-enriched yeast and selenium-enriched milk: effects on oxidative defence regulation. Br. J. Nutr. 99, 883-892

26 National Research Council (NRC). (1995) Nutrient Requirements of Laboratory Animals, $4^{\text {th }}$ revised ed. Washington D.C.: National Academies Press

27 Muller, A.S., Pallauf, J. and Most, E. (2002) Parameters of dietary selenium and vitamin E deficiency in growing rabbits. J. Trace Elem. Med. Biol. 16, 47-55

28 Chomczynski, P. and Sacchi, N. (1987) Single-step method of RNA isolation by acid guanidinium thiocyanate-phenol-chloroform extraction. Anal. Biochem. 162, 156-159

29 Tappel, M.E., Chaudiere, J. and Tappel, A.L. (1982) Glutathione peroxidase activities of animal tissues. Comp. Biochem. Physiol. (B) 73, 945-949

30 Weitzel, F., Ursini, F. and Wendel, A. (1990) Phospholipid hydroperoxide glutathione peroxidase in various mouse organs during selenium deficiency and repletion. Biochim. Biophys. Acta 1036, 88-94

31 Ricci, G., Caccuri, A.M., Lo Bello, M., Pastore, A., Piemonte, F. and Federici, G. (1994) Colorimetric and fluorometric assays of glutathione transferase based on 7-chloro-4nitrobenzo-2-oxa-1,3-diazole. Anal. Biochem. 218, 463-465

32 Doderer, K., Lutz-Wahl, S., Hauer, B. and Schmid, R.D. (2003) Spectrophotometric assay for epoxide hydrolase activity toward any epoxide. Anal. Biochem. 321, 131-141

33 Barnes, K.M., Evenson J.K., Raine, A.M. and Sunde, R.A. (2009) Transcript analysis of the selenoproteome indicates that the dietary selenium requirements of rats based on selenium-regulated selenoprotein mRNA levels are uniformly less than those based on glutathione peroxidase activity. J. Nutr. 139, 199-206

34 Haratake, M. Hongoh, M., Miyauchi, M., Hirakawa, R., Ono, M. and Nakayama, M. (2008) Albumin-mediated selenium transfer by a selenotrisulfide relay mechanism. Inorg. Chem. 47, 6273-6280

35 Suzuki, K.T., Ohta, Y. and Suzuki, N. (2006) Availability and metabolism of 77Semethylseleninic acid compared simultaneously with those of three related selenocompounds. Toxicol. Appl. Pharmacol. 217, 51-62

36 Ohta, Y. and Suzuki, K.T. (2008) Methylation and demethylation of intermediates selenide and methylselenol in the metabolism of selenium. Toxicol. Appl. Pharmacol. 226, 169-177

37 Koren, S. and Fantus, I.G. (2007) Inhibition of the protein tyrosine phosphatase PTP1B: potential therapy for obesity, insulin resistance and type-2 diabetes mellitus. Best Pract. Res. Clin. Endocrinol. Metab. 21, 621-640

38 Shimizu, S., Ugi, S., Maegawa, H., Egawa, K., Nishio, Y., Yoshizaki, T., Shi, K., Nagai, Y., Morino, K., Nemoto, K., Nakamura, T., Bryer-Ash, M. and Kashiwagi, A. (2003) Protein-tyrosine phosphatase $1 \mathrm{~B}$ as new activator for hepatic lipogenesis via sterol regulatory element-binding protein-1 gene expression. J. Biol. Chem. 278, 43095-43101 
39 Tonks, N.K. and Muthuswamy, S.K. (2007) A brake becomes an accelerator: PTP1B--a new therapeutic target for breast cancer. Cancer Cell 11, 214-216

40 Rocks, N., Paulissen, G., Quesada Calvo, F., Polette, M., Gueders, M., Munaut, C., Foidart, J.M., Noel, A., Birembaut, P. and Cataldo, D. (2006) Expression of a disintegrin and metalloprotease (ADAM and ADAMTS) enzymes in human non-small-cell lung carcinomas (NSCLC). Br. J. Cancer 94, 724-730

41 Lu, Y., Wang, X., Liu, Z., Jin, B., Chu, D., Zhai, H., Zhang, F., Li, K., Ren, G., MirandaVizuete, A., Guo, X. and Fan, D. (2008) Identification and distribution of thioredoxin-like 2 as the antigen for the monoclonal antibody MC3 specific to colorectal cancer. Proteomics 8, 2220-2229

42 Bengtson, N.W. and Linzer, D.I. (2000) Inhibition of tumor growth by the antiangiogenic placental hormone, proliferin-related protein. Mol. Endocrinol. 14, 1934-1943

43 Noda, T., Kumada, T., Takai, S., Matsushima-Nishiwaki, R., Yoshimi, N., Yasuda, E., Kato, K., Toyoda, H., Kaneoka, Y., Yamaguchi, A., Kozawa, O. (2007) Expression levels of heat shock protein 20 decrease in parallel with tumor progression in patients with hepatocellular carcinoma. Oncol. Rep. 17, 1309-1314

44 Pacini, A., Toscano, A., Cesati, V., Cozzi, A., Meli, E., Di Cesare Mannelli, L., Paternostro, F., Pacini, P. and Pellegrini-Giampietro, D.E. (2005) NAPOR-3 RNA binding protein is required for apoptosis in hippocampus. Brain Res. Mol. Brain Res. 140, 34-44

45 Cherñavsky, A.C., Rubio, A.E., Vanzulli, S., Rubinstein, N., de Rosa, S. and Fainboim, L. (2002) Evidences of the involvement of Bak, a member of the Bcl-2 family of proteins, in active coeliac disease. Autoimmunity 35, 29-37

46 Hamdi, M., Popeijus, H.E., Carlotti, F., Janssen, J.M., van der Burgt, C., CornelissenSteijger, P., van de Water, B., Hoeben, R.C., Matsuo, K. and van Dam, H. (2008) ATF3 and Fra1 have opposite functions in JNK- and ERK-dependent DNA damage responses. DNA Repair (Amst). 7, 487-496

47 Zhao, T., Zhang, H., Guo, Y. and Fan, Z. (2007) Granzyme K directly processes bid to release cytochrome $\mathrm{c}$ and endonuclease $\mathrm{G}$ leading to mitochondria-dependent cell death. J. Biol. Chem. 282, 12104-12111

48 Drubin, D.A. and Clawson, G.A. (2004) Spontaneous transformation of an immortalized hepatocyte cell line: potential role of a nuclear protease. Cancer Lett. 213, 39-48

49 Yun, X., Wu, Y., Yao, L., Zong, H., Hong, Y., Jiang, J., Yang, J., Zhang, Z. and Gu, J. (2007) CDK11 (p58) protein kinase activity is associated with Bcl-2 down-regulation in pro-apoptosis pathway. Mol Cell Biochem. 304, 213-218

50 Méplan, C., Nicol, F., Burtle, B., Crosley, L., Arthur, J., Mathers, J., Hesketh, J. (2009) Relative abundance of selenoprotein $P$ isoforms in human plasma depends on genotype, Se intake, and cancer status. Antioxid. Redox Signal. May 19. [Epub ahead of print]

51 Witt, S.H., Labeit, D., Granzier, H., Labeit, S. and Witt, C.C. (2005) Dimerization of the cardiac ankyrin protein CARP: implications for MARP titin-based signaling. J. Muscle Res. Cell Motil. 26, 401-408

52 Yao, D.L., Masonic, K., Petullo, D., Li, L. Y., Lincoln, C., Wibberley, L., Alderson, R.F. and Antonaccio, M. (1999) Pretreatment with intravenous FGF-13 reduces infarct volume and ameliorates neurological deficits following focal cerebral ischemia in rats. Brain Res. 18, 140-146

53 Barnoy, S., Supino-Rosin, L. and Kosower, N.S. (2000) Regulation of calpain and calpastatin in differentiating myoblasts: mRNA levels, protein synthesis and stability. Biochem. J. 351 Pt 2, 413-20

54 Higuchi, M., Yasuda, O., Kawamoto, H., Yotsui, T., Baba, Y., Ozaki, T., Maeda, N., Fukuo, K., Rakugi, H. and Ogihara, T. (2007) Tissue inhibitor of metalloproteinase-3 deficiency inhibits blood pressure elevation and myocardial microvascular remodeling induced by chronic administration of Nomega-nitro-L-arginine methylester in mice. Hypertens. Res. 30, 563-71

55 Rankinen, T., Rice, T., Boudreau, A., Leon, A.S., Skinner, J.S., Wilmore, J.H., Rao, D.C. and Bouchard, C. (2003) Titin is a candidate gene for stroke volume response to endurance training: the HERITAGE Family Study. Physiol. Genomics 15, 27-33 
56 Shang, Y.C., Wang, S.H., Xiong, F., Zhao, C.P., Peng, F.N., Feng, S.W., Li, M. S., Li, Y. and Zhang, C. (2007) Wnt3a signaling promotes proliferation, myogenic differentiation, and migration of rat bone marrow mesenchymal stem cells. Acta Pharmacol. Sin. 28, 1761-1774

57 Liu, J., Burkin, D.J. and Kaufman, S.J. (2008) Increasing alpha 7 beta 1-integrin promotes muscle cell proliferation, adhesion, and resistance to apoptosis without changing gene expression. Am. J. Physiol. Cell Physiol. 294, C627-640

58 Douziech, M., Grondin, G., Loranger, A., Marceau, N. and Blouin, R. (1998) Zonal induction of mixed lineage kinase ZPK/DLK/MUK gene expression in regenerating mouse liver. Biochem. Biophys. Res. Commun. 249, 927-932

59 Cheng, C.C., Liu, Y.H., Ho, C.C., Chao, W.T., Pei, R.J., Hsu, Y.H., Yeh, K.T., Ho, L.C., Tsai, M.C. and Lai, Y.S. (2008) The influence of plectin deficiency on stability of cytokeratin18 in hepatocellular carcinoma. J. Mol. Histol. 39, 209-216

60 Muraoka, R.S., Waltz, S.E. and Degen, S.J. (1999) Expression of hepatocyte growth factor-like protein is repressed by retinoic acid and enhanced by cyclic adenosine $3^{\prime}, 5^{\prime}-$ monophosphate response element-binding protein (CREB)-binding protein (CBP). Endocrinology 140, 187-196

61 Suter, L., Haiker, M., De Vera, M.C., Albertini, S. (2003) Effect of two 5-HT6 receptor antagonists on the rat liver: a molecular approach. Pharmacogenomics J. 3, 320-334

62 Spite, M., Baba, S.P., Ahmed, Y., Barski, O.A., Nijhawan, K., Petrash, J.M., Bhatnagar, A., Srivastava, S. (2007) Substrate specificity and catalytic efficiency of aldo-keto reductases with phospholipid aldehydes. Biochem. J. 405: 95-105 
608

609

610

Table 1 Genes from various functional areas (I-V) differentially regulated in rat liver by feeding selenite and selenate at two dietary levels (0.2 and 1.0 $\mathrm{mg} / \mathrm{kg}$ ) versus Se deficiency

\begin{tabular}{|c|c|c|c|c|c|}
\hline $\begin{array}{l}\text { Gene Bank Assoc } \\
\text { Number }\end{array}$ & Gene name & $\begin{array}{l}\text { Selenite } 0.2 \\
\text { ( } P \text { value })\end{array}$ & $\begin{array}{c}\text { Selenite1.0 } \\
\text { (P value) }\end{array}$ & $\begin{array}{c}\text { Selenate } 0.2 \\
\text { ( } \mathrm{P} \text { value) }\end{array}$ & $\begin{array}{l}\text { Selenate1.0 } \\
\text { ( } P \text { value) }\end{array}$ \\
\hline \multicolumn{6}{|c|}{ Area I: Genes related to phase I- or phase II detoxification } \\
\hline NM013215 & $\begin{array}{l}\text { Aflatoxin B1 Aldehyde } \\
\text { Reductase }\end{array}$ & $\begin{array}{c}4.07 \downarrow \\
(<0.001)\end{array}$ & $\begin{array}{c}3.14 \downarrow \\
(<0.001)\end{array}$ & $\begin{array}{c}4.10 \downarrow \\
(<0.001)\end{array}$ & $\begin{array}{l}3.25 \downarrow \\
(<0.001)\end{array}$ \\
\hline NM012540 & Cytochrome P450 & $\begin{array}{c}1.85 \uparrow \\
(0.434)\end{array}$ & $\begin{array}{l}1.84 \uparrow \\
(0.209)\end{array}$ & $\begin{array}{c}2.99 \uparrow \\
(0.022)\end{array}$ & $\begin{array}{c}2.70 \uparrow \\
(0.030)\end{array}$ \\
\hline M26125 & Epoxide Hydrolase & $\begin{array}{c}3.13 \downarrow \\
(<0.001)\end{array}$ & $\begin{array}{c}2.43 \downarrow \\
(<0.001)\end{array}$ & $\begin{array}{c}2.69 \\
(<0.001)\end{array}$ & $\begin{array}{l}1.74 \downarrow \\
(0.001)\end{array}$ \\
\hline NM017013 & $\begin{array}{l}\text { Glutathione-S- } \\
\text { Transferase A2 }\end{array}$ & $\begin{array}{c}2.49 \downarrow \\
(0.003)\end{array}$ & $\begin{array}{c}2.50 \downarrow \\
(0.002)\end{array}$ & $\begin{array}{l}2.28 \downarrow \\
(0.001)\end{array}$ & $\begin{array}{c}2.52 \downarrow \\
(0.001)\end{array}$ \\
\hline
\end{tabular}

Area II: Genes involved in the regulation of intermediary metabolism, the regulation of appetite and body weight or other metabolic processes

\begin{tabular}{|c|c|c|c|c|c|}
\hline NM031118 & $\begin{array}{ll}\text { Acyl Coenzyme } & \text { A } \\
\text { Cholesterol } & \\
\text { Acyltransferase 1 } & \end{array}$ & $\begin{array}{l}2.37 \uparrow * \\
(0.149)\end{array}$ & $\begin{array}{l}3.52 \uparrow * \\
(0.092)\end{array}$ & $\begin{array}{c}3 . \overline{44 \uparrow} \\
(0.018)\end{array}$ & $\begin{array}{c}3.00 \uparrow \\
(0.040)\end{array}$ \\
\hline AF206017 & $\begin{array}{l}\text { Agouti Related Protein } \\
\text { Precursor }\end{array}$ & $\begin{array}{l}1.95 \uparrow * \\
(0.208)\end{array}$ & $\begin{array}{c}3.57 \uparrow \\
(0.002)\end{array}$ & $\begin{array}{c}6.17 \uparrow \\
(0.017)\end{array}$ & $\begin{array}{l}3.00 \uparrow \\
(0.002)\end{array}$ \\
\hline NM019168 & Arginase II & $\begin{array}{l}1.10 \uparrow * \\
(0.860)\end{array}$ & $\begin{array}{l}5.88 \uparrow \\
(0.046)\end{array}$ & $\begin{array}{l}3.14 \uparrow \\
(0.014)\end{array}$ & $\begin{array}{l}3.25 \uparrow \\
(0.006)\end{array}$ \\
\hline S49760 & $\begin{array}{l}\text { Diacylglycerol Kinase, } \\
\text { 80k-DG Kinase }\end{array}$ & $\begin{array}{l}1.07 \downarrow * \\
(0.876)\end{array}$ & $\begin{array}{l}1.52 \downarrow * \\
(0.289)\end{array}$ & $\begin{array}{c}2.39 \downarrow \\
(0.014)\end{array}$ & $\begin{array}{c}3.03 \downarrow \\
(0.008)\end{array}$ \\
\hline NM019333 & $\begin{array}{l}\text { Fructose-6-Phosphate- } \\
\text { 2-Kinase }\end{array}$ & $\begin{array}{l}3.27 \uparrow * \\
(0.176) \\
\end{array}$ & $\begin{array}{l}2.74 \uparrow * \\
(0.161)\end{array}$ & $\begin{array}{c}3.41 \uparrow \\
(0.012) \\
\end{array}$ & $\begin{array}{c}4.43 \uparrow \\
(0.005) \\
\end{array}$ \\
\hline AF058787 & Heme Oxygenase 3 & $\begin{array}{l}1.16 \downarrow * \\
(0.706)\end{array}$ & $\begin{array}{l}1.28 \downarrow * \\
(0.445)\end{array}$ & $\begin{array}{c}2.55 \downarrow \\
(<0.001)\end{array}$ & $\begin{array}{c}3.30 \downarrow \\
(<0.001)\end{array}$ \\
\hline NM024365 & $\begin{array}{l}\text { 5-hydroxytryptamine } \\
\text { serotonin receptor } 6\end{array}$ & $\begin{array}{l}2.05 \uparrow * \\
(0.214)\end{array}$ & $\begin{array}{l}1.10 \uparrow * \\
(0.888)\end{array}$ & $\begin{array}{c}4.15 \uparrow \\
(0.005)\end{array}$ & $\begin{array}{c}7.13 \uparrow \\
(<0.001)\end{array}$ \\
\hline NM013064 & $\begin{array}{ll}\text { Hypocretin } & \text { Orexin } \\
\text { Receptor } 1 & \\
\end{array}$ & $\begin{array}{l}1.61 \uparrow^{*} \\
(0.549)\end{array}$ & $\begin{array}{l}1.90 \uparrow^{*} \\
(0.385)\end{array}$ & $\begin{array}{c}3.32 \uparrow \\
(0.008) \\
\end{array}$ & $\begin{array}{c}3.36 \uparrow \\
(0.008) \\
\end{array}$ \\
\hline NM012614 & $\begin{array}{ll}\text { Neuropeptide } & Y \\
\text { Precursor } & \\
\end{array}$ & $\begin{array}{l}2.33 \uparrow * \\
(0.321)\end{array}$ & $\begin{array}{l}1.81 \uparrow * \\
(0.213)\end{array}$ & $\begin{array}{c}3.30 \uparrow \\
(0.004)\end{array}$ & $\begin{array}{l}3.70 \uparrow \\
(0.002)\end{array}$ \\
\hline NM020099 & $\begin{array}{l}\text { Ob Receptor Gene } \\
\text { Related Protein }\end{array}$ & $\begin{array}{l}2.49 \uparrow * \\
(0.297)\end{array}$ & $\begin{array}{l}2.18 \uparrow * \\
(0.377)\end{array}$ & $\begin{array}{l}3.00 \uparrow \\
(0.046)\end{array}$ & $\begin{array}{l}3.96 \uparrow \\
(0.019)\end{array}$ \\
\hline NM022626 & $\begin{array}{l}\text { Phosphorylase } \\
\text { Kinase Alpha Subunit }\end{array}$ & $\begin{array}{l}3.25 \uparrow^{*} \\
(0.151)\end{array}$ & $\begin{array}{l}3.35 \uparrow * \\
(0.071) \\
\end{array}$ & $\begin{array}{l}3.60 \uparrow \\
(0.027) \\
\end{array}$ & $\begin{array}{c}5.48 \uparrow \\
(0.005) \\
\end{array}$ \\
\hline NM012637 & $\begin{array}{l}\text { Protein } \\
\text { Phosphatase 1B }\end{array}$ & $\begin{array}{l}1.84 \uparrow * \\
(0.003)\end{array}$ & $\begin{array}{l}1.60 \uparrow * \\
(0.007)\end{array}$ & $\begin{array}{c}3.14 \uparrow \\
(0.024)\end{array}$ & $\begin{array}{c}2.53 \uparrow \\
(<0.001)\end{array}$ \\
\hline M58040 & Transferrin Receptor & $\begin{array}{l}3.40 \uparrow * \\
(0.087) \\
\end{array}$ & $\begin{array}{l}2.53 \uparrow * \\
(0.169) \\
\end{array}$ & $\begin{array}{c}3.84 \uparrow \\
(0.003) \\
\end{array}$ & $\begin{array}{c}4.03 \uparrow \\
(0.003) \\
\end{array}$ \\
\hline \multicolumn{6}{|c|}{ Area III: Genes related to the cell cycle, cell development, apoptosis or tumour metabolism } \\
\hline NM024400 & ADAMTS-1 & $\begin{array}{l}1.32 \downarrow * \\
(0.330)\end{array}$ & $\begin{array}{l}1.75 \downarrow * \\
(0.055)\end{array}$ & $\begin{array}{c}2.48 \downarrow \\
(0.006) \\
\end{array}$ & $\begin{array}{l}2.50 \downarrow \\
(0.006)\end{array}$ \\
\hline X74294 & Alpha 7c Integrin & $\begin{array}{l}3.11 \uparrow * \\
(0.025)\end{array}$ & $\begin{array}{l}3.33 \uparrow^{*} \\
(0.055)\end{array}$ & $\begin{array}{c}4.50 \uparrow \\
(0.002) \\
\end{array}$ & $\begin{array}{c}4.11 \uparrow \\
(0.003) \\
\end{array}$ \\
\hline$\overline{\mathrm{D} 29960 \overline{\text { (Table 2) }}}$ & $\begin{array}{l}\text { Alphab crystallin-related } \\
\text { protein }\end{array}$ & $\begin{array}{c}1.90 \uparrow \\
(0.219)\end{array}$ & $\begin{array}{c}1.59 \uparrow \\
(0.453)\end{array}$ & $\begin{array}{c}5.85 \uparrow \\
(0.002)\end{array}$ & $\begin{array}{c}4.10 \uparrow \\
(0.005)\end{array}$ \\
\hline$\overline{\mathrm{D} 25543(\text { (Table 2) }}$ & Rat gcp360 & $\begin{array}{c}1.59 \uparrow \\
(0.498)\end{array}$ & $\begin{array}{c}2.26 \uparrow \\
(0.178)\end{array}$ & $\begin{array}{c}4.67 \uparrow \\
(<0.001)\end{array}$ & $\begin{array}{c}5.64 \uparrow \\
(<0.001)\end{array}$ \\
\hline AF090695 & NAPOR-3 & $\begin{array}{l}1.08 \downarrow * \\
(0.839)\end{array}$ & $\begin{array}{l}1.03 \downarrow * \\
(0.924)\end{array}$ & $\begin{array}{c}2.34 \downarrow \\
(0.019)\end{array}$ & $\begin{array}{c}2.54 \downarrow \\
(0.017)\end{array}$ \\
\hline
\end{tabular}

611 
612 Table $1 \quad$ Continued

\begin{tabular}{|c|c|c|c|c|c|}
\hline $\begin{array}{l}\text { Gene Bank Assoc } \\
\text { Number }\end{array}$ & Gene name & $\begin{array}{c}\text { Selenite } 0.2 \\
\text { ( } P \text { value) }\end{array}$ & $\begin{array}{c}\text { Selenite1.0 } \\
\text { ( } P \text { value) }\end{array}$ & \begin{tabular}{|c|} 
Selenate 0.2 \\
(P value)
\end{tabular} & $\begin{array}{l}\text { Selenate1.0 } \\
\text { ( } P \text { value) }\end{array}$ \\
\hline \multicolumn{6}{|c|}{ Area III: Genes related to the cell cycle, cell development, apoptosis or tumour metabolism } \\
\hline NM053812 & BCL 2 Antagonist 1 & $\begin{array}{l}1.37 \uparrow * \\
(0.517) \\
\end{array}$ & $\begin{array}{l}1.72 \uparrow * \\
(0.349) \\
\end{array}$ & $\begin{array}{l}2.81 \uparrow \\
(0.011) \\
\end{array}$ & $\begin{array}{c}3.16 \uparrow \\
(0.010) \\
\end{array}$ \\
\hline$\overline{Z 12298}$ & \begin{tabular}{|ll} 
Dermatan & Sulfate \\
Proteoglycan II & \\
\end{tabular} & $\begin{array}{l}2.87 \uparrow * \\
(0.225)\end{array}$ & $\begin{array}{l}2.57 \uparrow * \\
(0.284)\end{array}$ & $\begin{array}{l}3.98 \uparrow \\
(0.009)\end{array}$ & $\begin{array}{l}3.63 \uparrow \\
(0.011)\end{array}$ \\
\hline NM030585 & FOS Related Antigen & $\begin{array}{l}3.51 \uparrow * \\
(0.122)\end{array}$ & $\begin{array}{l}3.27 \uparrow * \\
(0.186) \\
\end{array}$ & $\begin{array}{l}6.54 \uparrow \\
(0.009) \\
\end{array}$ & $\begin{array}{c}4.67 \uparrow \\
(0.004)\end{array}$ \\
\hline NM017119 & Granzyme K & 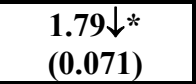 & $\begin{array}{l}1.13 \downarrow * \\
(0.731)\end{array}$ & $\begin{array}{l}2.48 \\
(0.005)\end{array}$ & $\begin{array}{c}2.46 \downarrow \\
(0.009)\end{array}$ \\
\hline NM017145 & Mast Cell Protease 1 & $\begin{array}{l}1.77 \uparrow * \\
(0.488) \\
\end{array}$ & $\begin{array}{l}2.47 \uparrow * \\
(0.274) \\
\end{array}$ & $\begin{array}{l}3.72 \uparrow \\
(0.013) \\
\end{array}$ & $\begin{array}{c}2.73 \uparrow \\
(0.040) \\
\end{array}$ \\
\hline NM013055 & 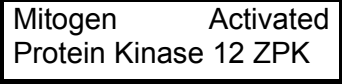 & $\begin{array}{l}\text { 2.32个* } \\
(\mathbf{0 . 3 5 1 )} \\
\end{array}$ & $\begin{array}{l}\text { 1.99个* } \\
(0.357) \\
\end{array}$ & $\begin{array}{c}4.03 \uparrow \\
(0.050)\end{array}$ & $\begin{array}{c}3.48 \uparrow \\
(0.040) \\
\end{array}$ \\
\hline U15425 & P58 & $\begin{array}{l}1.42 \uparrow * \\
(0.625)\end{array}$ & $\begin{array}{l}1.81 \uparrow^{*} \\
(0.087)\end{array}$ & $\begin{array}{c}2.85 \uparrow \\
(0.007)\end{array}$ & $\begin{array}{l}2.09 \uparrow \\
(0.036)\end{array}$ \\
\hline NM032614 & $\begin{array}{l}\text { PKCQ Interacting } \\
\text { Protein Picot }\end{array}$ & $\begin{array}{l}1.21 \downarrow * \\
(0.582)\end{array}$ & $\begin{array}{l}1.03 \downarrow * \\
(0.914)\end{array}$ & $\begin{array}{c}2.30 \downarrow \\
(0.006)\end{array}$ & $\begin{array}{l}2.08 \downarrow \\
(0.008)\end{array}$ \\
\hline U96275 & Plectin 1 & $\begin{array}{l}\text { 2.00个* } \\
(0.296)\end{array}$ & $\begin{array}{l}3.28 \uparrow * \\
(0.070)\end{array}$ & $\begin{array}{c}5.14 \uparrow \\
(<0.001)\end{array}$ & $\begin{array}{c}5.54 \uparrow \\
(<0.001)\end{array}$ \\
\hline NM053364 & $\begin{array}{ll}\begin{array}{l}\text { Proliferin } \\
\text { Protein }\end{array} & \text { Related } \\
\end{array}$ & $\begin{array}{l}2.33 \uparrow * \\
(0.275)\end{array}$ & $\begin{array}{l}2.68 \uparrow^{* *} \\
(0.228)\end{array}$ & $\begin{array}{c}4.15 \uparrow \\
(0.002) \\
\end{array}$ & $\begin{array}{c}3.61 \uparrow \\
(0.002) \\
\end{array}$ \\
\hline NM019906 & $\begin{array}{|ll|}\text { Rapamycin } & \text { And } \\
\text { FKBP12 Target-1 } & \\
\end{array}$ & $\begin{array}{l}2.43 \uparrow \% \\
(0.095)\end{array}$ & $\begin{array}{l}2 . \overline{9 \uparrow \uparrow *} \\
(0.174)\end{array}$ & $\begin{array}{c}3.84 \uparrow \\
(0.010)\end{array}$ & $\begin{array}{c}3.84 \uparrow \\
(<0.001)\end{array}$ \\
\hline \multicolumn{6}{|c|}{ Area IV: Genes related to inflammatory or immunomodulatory response } \\
\hline NM021583 & \begin{tabular}{|l|l|} 
Ind. Prostaglandine \\
Synthase
\end{tabular} & $\begin{array}{r}1.73 \uparrow * \\
(0.314) \\
\end{array}$ & $\begin{array}{l}2.64 \uparrow * \\
(0.074) \\
\end{array}$ & $\begin{array}{c}3.33 \uparrow \\
(0.023) \\
\end{array}$ & $\begin{array}{c}4.58 \uparrow \\
(<0.001) \\
\end{array}$ \\
\hline NM057193 & Interleukin 10 Receptor & $\begin{array}{l}1.94 \uparrow * \\
(0.220)\end{array}$ & $\begin{array}{l}2.67 \uparrow * \\
(0.065) \\
\end{array}$ & $\begin{array}{c}2.81 \uparrow \\
(0.010) \\
\end{array}$ & $\begin{array}{c}2.84 \uparrow \\
(0.009) \\
\end{array}$ \\
\hline NM020542 & $\begin{array}{l}\text { Macrophage Inflamm. } \\
\text { Protein } 1 \text { Alpha Rec. }\end{array}$ & $\begin{array}{l}1.48 \downarrow * \\
(0.299) \\
\end{array}$ & $\begin{array}{l}1.33 \downarrow * \\
(0.485) \\
\end{array}$ & $\begin{array}{c}3.17 \downarrow \\
(0.004) \\
\end{array}$ & $\begin{array}{c}3.86 \downarrow \\
(0.003) \\
\end{array}$ \\
\hline M34097 & $\begin{array}{l}\text { Rat Natural Killer Cell } \\
\text { Protease } 1\end{array}$ & $\begin{array}{l}1.87 \uparrow * \\
(0.334)\end{array}$ & $\begin{array}{l}2.40 \uparrow * \\
(0.018)\end{array}$ & $\begin{array}{c}2.59 \uparrow \\
(0.005)\end{array}$ & $\begin{array}{c}3.75 \uparrow \\
(0.004)\end{array}$ \\
\hline
\end{tabular}

Area V: Genes with other functions (hormonal function, receptor function, signal transduction)

\begin{tabular}{|c|c|c|c|c|c|}
\hline NM013220 & $\begin{array}{l}\text { Cardiac Ankyrin Repeat } \\
\text { Protein }\end{array}$ & $\begin{array}{l}2.00 \downarrow * \\
(0.115)\end{array}$ & $\begin{array}{l}1.46 \downarrow * \\
(0.319)\end{array}$ & $\begin{array}{l}3.05 \downarrow \\
(0.043)\end{array}$ & $\begin{array}{l}2.92 \downarrow \\
(0.045)\end{array}$ \\
\hline S78641 & $\begin{array}{l}\text { Cycl. Adenosine } 3^{\prime}, 5^{\prime}- \\
\text { Monophosphate Resp. } \\
\text { Elem. Binding Protein }\end{array}$ & $\begin{array}{l}1.86 \uparrow * \\
(0.421)\end{array}$ & $\begin{array}{l}1.53 \uparrow^{*} \\
(0.451)\end{array}$ & $\begin{array}{c}3.29 \uparrow \\
(0.018)\end{array}$ & $\begin{array}{c}2.58 \uparrow \\
(0.020)\end{array}$ \\
\hline NM053428 & $\begin{array}{ll}\text { Fibroblast } & \text { Growth } \\
\text { Factor 13 } & \\
\end{array}$ & $\begin{array}{l}2.80 \uparrow * \\
(0.129) \\
\end{array}$ & $\begin{array}{l}3.14 \uparrow * \\
(0.078) \\
\end{array}$ & $\begin{array}{c}4.63 \uparrow \\
(<0.001) \\
\end{array}$ & $\begin{array}{c}4.09 \uparrow \\
(<0.001) \\
\end{array}$ \\
\hline NM012750 & $\begin{array}{lrr}\text { Glial Cell } & \text { Line } & \text { Der. } \\
\text { Neurotrophic } & \text { Factor } \\
\text { Rec. Beta } & \\
\end{array}$ & $\begin{array}{l}1.57 \uparrow * \\
(0.524)\end{array}$ & $\begin{array}{l}2.41 \uparrow^{*} \\
(0.332)\end{array}$ & $\begin{array}{c}3.88 \uparrow \\
(0.006)\end{array}$ & $\begin{array}{c}3.66 \uparrow \\
(0.019)\end{array}$ \\
\hline NM019152 & $\begin{array}{ll}\text { MU Calpain Large } \\
\text { Subunit }\end{array}$ & $\begin{array}{l}1.53 \uparrow * \\
(0.430)\end{array}$ & $\begin{array}{l}2.69 \uparrow * \\
(0.227)\end{array}$ & $\begin{array}{l}4.00 \uparrow \\
(0.013)\end{array}$ & $\begin{array}{c}4.55 \uparrow \\
(0.006)\end{array}$ \\
\hline NM012886 & \begin{tabular}{|lrl} 
Tissue Inhibitor & of \\
Metalloproteinase 3
\end{tabular} & $\begin{array}{l}1.90 \uparrow * \\
(0.358)\end{array}$ & $\begin{array}{c}4.44 \uparrow \\
(0.046)\end{array}$ & $\begin{array}{c}3.76 \uparrow \\
(0.011)\end{array}$ & $\begin{array}{c}2.68 \uparrow \\
(0.045)\end{array}$ \\
\hline AJ401157 (Table 2) & Titin & $\begin{array}{l}1.00 \uparrow * \\
(0.999)\end{array}$ & $\begin{array}{l}1.53 \uparrow * \\
(0.204)\end{array}$ & $\begin{array}{c}2.72 \uparrow \\
(0.016)\end{array}$ & $\begin{array}{c}3.62 \uparrow \\
(0.012)\end{array}$ \\
\hline NM053402 & $\begin{array}{l}\text { Wingless Type MMTV } \\
\text { Integration Site Family }\end{array}$ & $\begin{array}{l}2.91 \uparrow * \\
(0.188)\end{array}$ & $\begin{array}{c}6.16 \uparrow \\
(0.011)\end{array}$ & $\begin{array}{l}3.51 \uparrow \\
(0.039)\end{array}$ & $\begin{array}{c}5.44 \uparrow \\
(0.008)\end{array}$ \\
\hline
\end{tabular}

$613 *$ indicate that selenite supplementation regulated most genes into the same direction as selenate

614 supplementation (up $\uparrow / d o w n \downarrow$ ), but that these effects were not significant $(P<0.05)$; genes occurring

615 additionally in Table 2 are highlighted on a grey background and a reference remark to Table 2 is given 
616 Table 2 Selection of genes differentially regulated in rat liver comparing selenate

617

\begin{tabular}{|c|c|c|c|c|c|c|}
\hline $\begin{array}{l}\text { Gene Bank } \\
\text { Assoc } \\
\text { Number }\end{array}$ & Gene name & $\begin{array}{c}\text { Selenate } \\
\text { vs. Selenite } \\
\text { [both levels] } \\
\text { (P value) } \\
\text { [Selenate0.2 vs. } \\
\text { Selenite } 0.2 \text { ] } \\
\text { [Selenate1.0 vs. } \\
\text { Selenite1.0] }\end{array}$ & $\begin{array}{l}\text { Selenite } 0.2 \\
\text { vs. } \\
\text { 0Se } \\
\text { (P value) }\end{array}$ & $\begin{array}{l}\text { Selenite1.0 } \\
\text { vs. } \\
\text { 0Se } \\
\text { (P value) }\end{array}$ & $\begin{array}{c}\text { Selenate } 0.2 \\
\text { vs. } \\
\text { 0Se } \\
\text { (P value) }\end{array}$ & $\begin{array}{c}\text { Selenate1.0 } \\
\text { vs. } \\
\text { 0Se } \\
\text { (P value) }\end{array}$ \\
\hline NM012850 & $\begin{array}{l}\text { Putative growth } \\
\text { horm. releasing } \\
\text { hormone } \\
\text { receptor-related } \\
\text { protein } \\
\end{array}$ & $\begin{array}{l}3.22 \downarrow \\
(0.005) \\
{[2.51 \downarrow]} \\
{[4.03 \downarrow]}\end{array}$ & $\begin{array}{l}1.11 \downarrow \\
(0.628)\end{array}$ & $\begin{array}{l}1.27 \uparrow \\
(0.525)\end{array}$ & $\begin{array}{l}2.80 \downarrow \\
(0.020)\end{array}$ & $\begin{array}{l}3.17 \downarrow \\
(0.014)\end{array}$ \\
\hline ** U56936 & Nkr-p1b & $\begin{array}{l}2.42 \downarrow \\
(0.007) \\
{[4.00 \downarrow} \\
{[1.69 \downarrow} \\
\end{array}$ & $\begin{array}{l}1.59 \uparrow \\
(0.522)\end{array}$ & $\begin{array}{l}1.46 \uparrow \\
(0.601)\end{array}$ & $\begin{array}{l}2.51 \downarrow \\
(0.523)\end{array}$ & $\begin{array}{l}1.14 \downarrow \\
(0.886)\end{array}$ \\
\hline $\begin{array}{l}\text { *AJ401157 } \\
\text { (Table 1) }\end{array}$ & Titin & $\begin{array}{l}2.50 \uparrow \\
(0.013) \\
{[2.72 \uparrow]} \\
{[2.36 \uparrow} \\
\end{array}$ & $\begin{array}{l}1.00 \uparrow \\
(0.999)\end{array}$ & $\begin{array}{l}1.53 \uparrow \\
(0.204)\end{array}$ & $\begin{array}{l}2.72 \uparrow \\
(0.016)\end{array}$ & $\begin{array}{l}3.61 \uparrow \\
(0.012)\end{array}$ \\
\hline $\begin{array}{l}{ }^{*} \text { D25543 } \\
\text { (Table 1) }\end{array}$ & Rat gcp360 & $\begin{array}{l}2.67 \uparrow \\
(0.004) \\
{[2.92 \uparrow]} \\
{[1.74 \uparrow]}\end{array}$ & $\begin{array}{l}1.59 \uparrow \\
(0.498)\end{array}$ & $\begin{array}{l}2.26 \uparrow \\
(0.178)\end{array}$ & $\begin{array}{c}4.67 \uparrow \\
(<0.001)\end{array}$ & $\begin{array}{c}5.64 \uparrow \\
(<0.001)\end{array}$ \\
\hline AF100789 & $\begin{array}{l}\text { G protein-coupled } \\
\text { receptor gpr55 }\end{array}$ & $\begin{array}{l}2,74 \uparrow \\
(0.002) \\
{[3.59 \uparrow]} \\
{[2.24 \uparrow]} \\
\end{array}$ & $\begin{array}{l}1.37 \downarrow \\
(0.501)\end{array}$ & $\begin{array}{l}1.27 \uparrow \\
(0.639)\end{array}$ & $\begin{array}{l}2.61 \uparrow \\
(0.015)\end{array}$ & $\begin{array}{l}2.86 \uparrow \\
(0.008)\end{array}$ \\
\hline $\begin{array}{l}{ }^{*} \text { D29960 } \\
\text { (Table 1) }\end{array}$ & $\begin{array}{l}\text { Alphab crystallin- } \\
\text { related protein }\end{array}$ & $\begin{array}{l}2.85 \uparrow \\
(0.004) \\
{[3.07 \uparrow]} \\
{[2.57 \uparrow]}\end{array}$ & $\begin{array}{l}1.90 \uparrow \\
(0.219)\end{array}$ & $\begin{array}{l}1.59 \uparrow \\
(0.453)\end{array}$ & $\begin{array}{l}5.85 \uparrow \\
(0.002)\end{array}$ & $\begin{array}{l}4.10 \uparrow \\
(0.005)\end{array}$ \\
\hline S64315 & $\begin{array}{l}\text { Metabotropic } \\
\text { glutamate } \\
\text { receptor subtype } \\
5 b\end{array}$ & $\begin{array}{l}3.72 \uparrow \\
(0.047) \\
{[6.82 \uparrow]} \\
{[1.81 \uparrow]} \\
\end{array}$ & $\begin{array}{l}1.45 \downarrow \\
(0.407)\end{array}$ & $\begin{array}{l}1.18 \uparrow \\
(0.843)\end{array}$ & $\begin{array}{l}4.68 \uparrow \\
(0.006)\end{array}$ & $\begin{array}{l}2.20 \uparrow \\
(0.002)\end{array}$ \\
\hline NM024365 & $\begin{array}{l}\text { 5-hydroxy- } \\
\text { tryptamine } \\
\text { receptor } 6\end{array}$ & $\begin{array}{l}3.81 \uparrow \\
(0.006) \\
{[2.02 \uparrow]} \\
{[7.84 \uparrow]} \\
\end{array}$ & $\begin{array}{l}2.04 \uparrow \\
(0.214)\end{array}$ & $\begin{array}{l}1.10 \downarrow \\
(0.887)\end{array}$ & $\begin{array}{l}4.14 \uparrow \\
(0.005)\end{array}$ & $\begin{array}{c}7.12 \uparrow \\
(<0.001)\end{array}$ \\
\hline${ }_{1}^{* *} \mathrm{NM05378}$ & $\begin{array}{l}\text { Aldose-reductase- } \\
\text { like (akr1-b7) }\end{array}$ & $\begin{array}{l}5.14 \uparrow \\
(0.014) \\
{[4.24 \uparrow]} \\
{[6.20 \uparrow]} \\
\end{array}$ & $\begin{array}{l}1.13 \downarrow \\
(0.823)\end{array}$ & $\begin{array}{l}1.36 \downarrow \\
(0.637)\end{array}$ & $\begin{array}{l}3.75 \uparrow \\
(0.017)\end{array}$ & $\begin{array}{l}4.56 \uparrow \\
(0.007)\end{array}$ \\
\hline ** U56863 & Ly-49.9 antigen & $\begin{array}{l}7.92 \uparrow \\
(0.003) \\
{[4.81 \uparrow} \\
{[15.8 \Uparrow]}\end{array}$ & $\begin{array}{l}1.49 \downarrow \\
(0.296)\end{array}$ & $\begin{array}{l}3.78 \downarrow \\
(\mathbf{0 . 0 3 3})\end{array}$ & $\begin{array}{l}3.23 \uparrow \\
(0.004)\end{array}$ & $\begin{array}{l}4.16 \uparrow \\
(0.020)\end{array}$ \\
\hline
\end{tabular}

Selenate

enate0. 2 vs

nate1.0 vs. enite1.0]

0.005)

$2.42 \downarrow$

.007)

$1.69 \downarrow$

(0.013)

$2.72 \uparrow$

(0.004)

2,74

$0.002)$

$2.85 \uparrow$

$0.004)$

[3.07介]

$3.72 \uparrow$

(0.006)

$5.14 \uparrow$

$(0.014)$

$7.92 \uparrow$

[4.81介

[15.8

619

620

621 background. Moreover a reference to Table 1 is given. Genes regulated in a contrary manner by selenate and selenite are highlighted with ** and appear on a light grey background. Genes regulated indifferently by selenite, but consistently by selenate appear on a white background. 
622

623

624

625

626

627

628

629

630

631

632

633

634

635

636

637

638

639

640

641

642

643

644

645

646

647

648

649

650

651

652

653

654

655

656

657

658

659

660

661

662

663

Table 3 Hierarchy of functional selenoproteins in rat liver as analyzed by microarray analysis

\begin{tabular}{|l|c|c|c|c|c|}
\hline Selenoprotein & $\begin{array}{c}\text { Selenite 0.2 } \\
\text { vs. 0 Se }\end{array}$ & $\begin{array}{c}\text { Selenate 0.2 } \\
\text { vs. 0 Se }\end{array}$ & $\begin{array}{c}\text { Selenite 1.0 } \\
\text { vs. 0 Se }\end{array}$ & $\begin{array}{c}\text { Selenate 1.0 } \\
\text { vs. 0 Se }\end{array}$ & $\begin{array}{c}\text { Mean P } \\
\text { value for } \\
\text { extent of } \\
\text { regulation }\end{array}$ \\
\hline GPx1 & 6.99 & 5.48 & 6.62 & 5.88 & 0.0056 \\
\hline SelP & 2.06 & 1.71 & 2.11 & 1.94 & 0.0112 \\
\hline 15 kDa Sep & 1.15 & 1.54 & 1.30 & 1.32 & 0.0210 \\
\hline SelW & 1.15 & 1.54 & 2.18 & 1.21 & 0.0230 \\
\hline DIO1 & 1.57 & 1.52 & 1.62 & 1.24 & 0.0335 \\
\hline GPx4 & 1.33 & 1.24 & 1.32 & 1.31 & 0.0883 \\
\hline
\end{tabular}


664 FIGURE 1

665 A

666

667

668

669

670

671

672

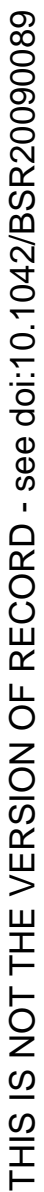

A

673

674

675

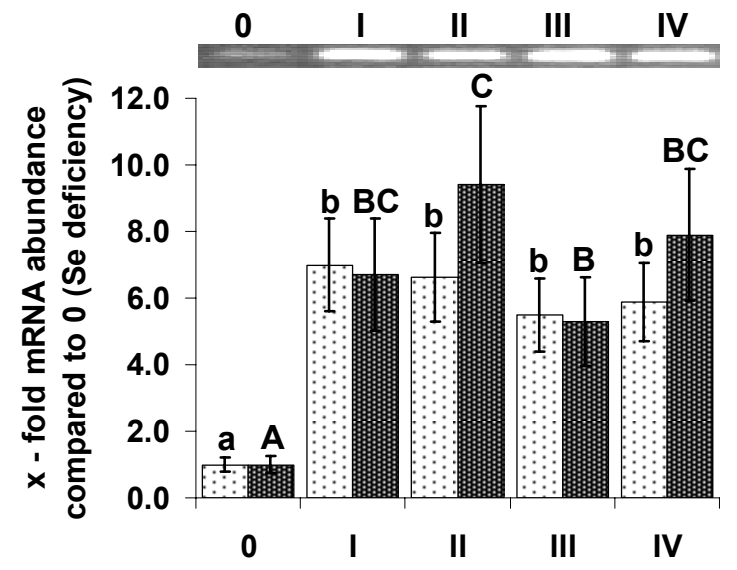

676

Microarray

Analyzed

677

678

679

680

681

682

683

B

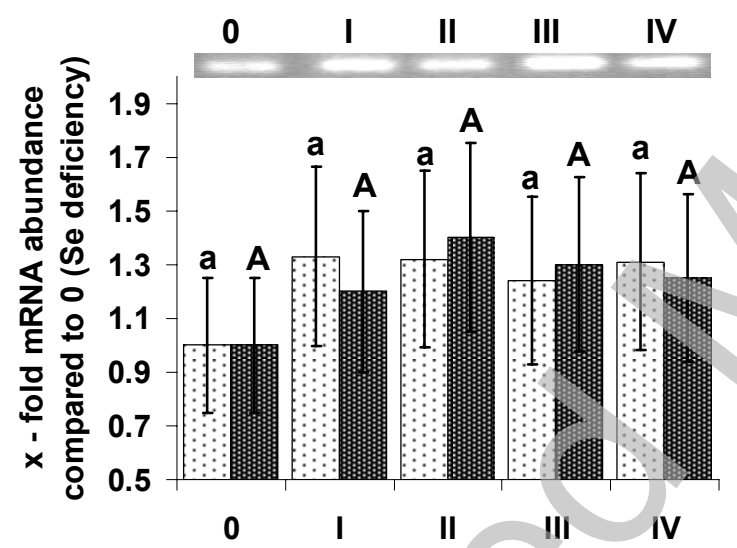

684

685

$\therefore$ Microarray

Analyzed

686

687 C

688

689

690

691

692

693

694

695

696

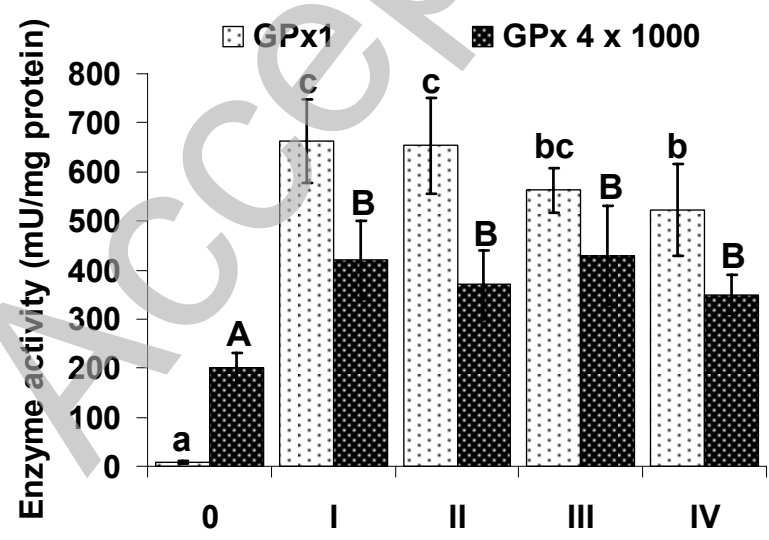


697

698

699

700

701

702

703

704

705

706

707

708

709

710

711

712

713

714

715

716

717

718

719

720

721

722

723

724

725

726

727

728

729

730

731

732

733

734

735

736

737

738

739

740

741

742

743

744

745

746
Figure 1 Regulation of GPx1 and GPx4 in rat liver after 8 weeks of Se deficiency (0) compared to Se supplementation with 0.2 or $1.0 \mathrm{mg} \mathrm{Se} / \mathrm{kg}$ diet as selenite (I, III) or selenate (II, IV)

A) mRNA expression of GPx 1 as analyzed by MA analysis and controlled by 2-step RT$P C R ; \quad B) m R N A$ expression of GPx 4 as analyzed by MA analysis and controlled by 2-step $\begin{array}{lll}R T-P C R & \text { C) GPx1- and GPx4-activity }\end{array}$

Values are means $\pm S D$. Significant differences between means $(p<0.05)$ are indicated by different small letters for MA expression data $(A, B)$, by different capital letters for 2-step $R T$ $P C R(A, B)$, by different small letters for GPx1 activity and by different capital letters for GPx4 activity $(C)$. 
747

748

749

750

751

752

753

754

755

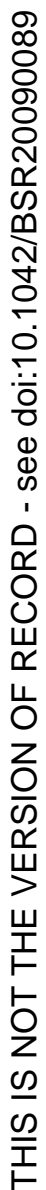

756

757

758

759

760

761

762

763

764

765

766

767

768

769

770

771

772

773

774

775

776

777

778

779

\section{FIGURE 2}

A

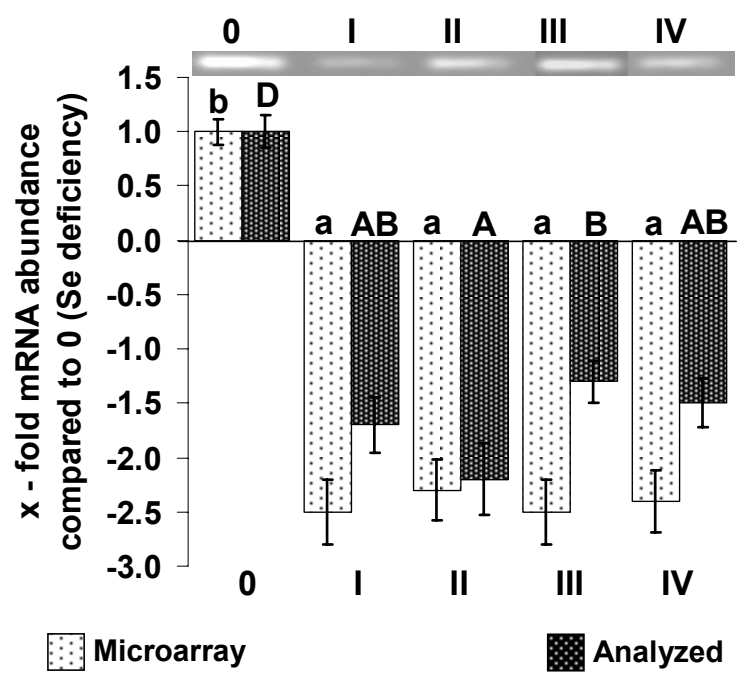

B

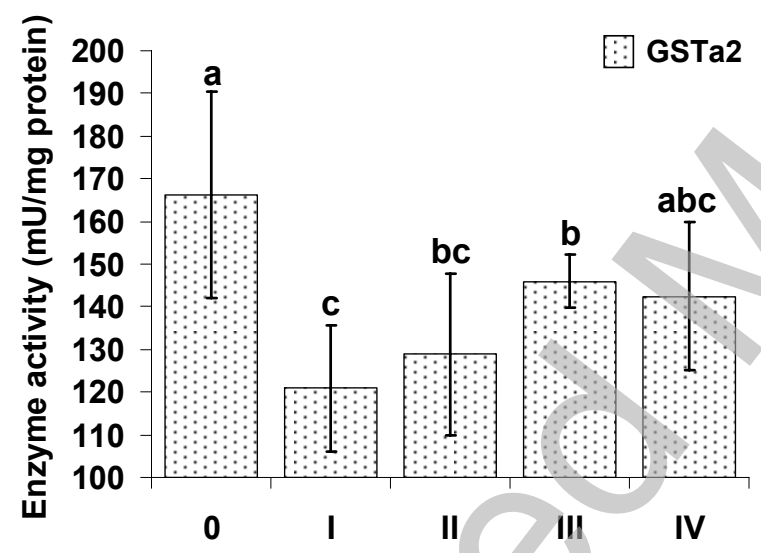

C

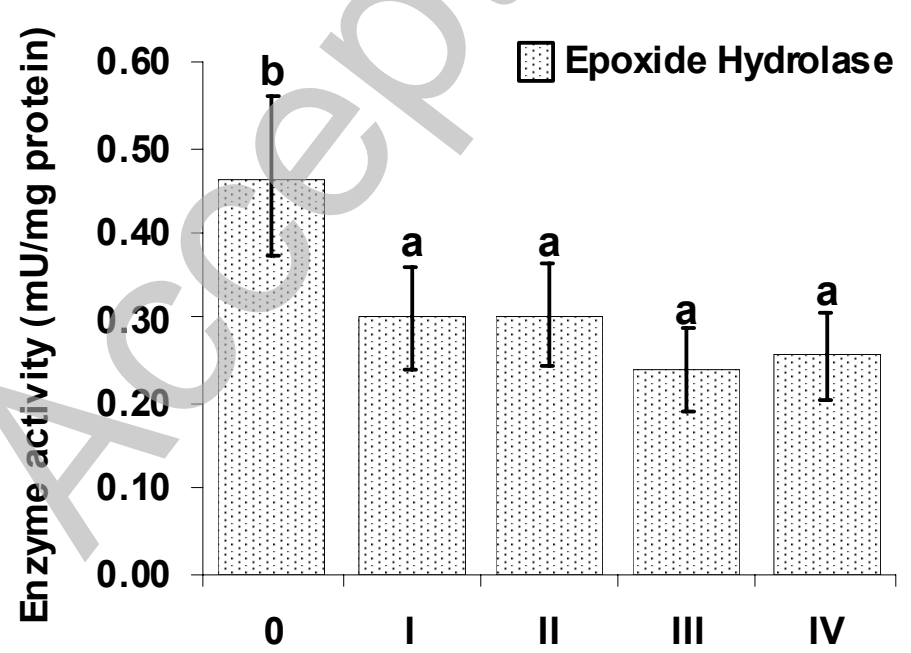


780

781

782

783

784

785

786

787

788

789

790

791

792

793

794

795

796

797

798

799

800

801

802

803

804

805

806

807

808

809

810

811

812

813

814

815

816

817

818

819

820

821

822

823

824

825

826

827

828

829
Figure 2 Regulation of GSTa2 and epoxide hydrolase in rat liver after 8 weeks of Se deficiency (0) compared to Se supplementation with 0.2 or $1.0 \mathrm{mg}$ Se/kg diet as selenite (I, III) or selenate (II, IV)

A) mRNA expression of GSTa2 as analyzed by MA analysis and controlled by 2-step RT-

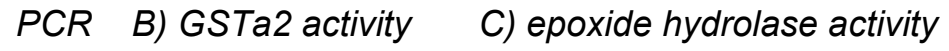

Values are means $\pm S D$. Significant differences between means $(p<0.05)$ are indicated by different small letters for MA expression data for GSTa2 (A), by different capital letters for 2 step RT-PCR of GSTa2 (A), and by different small letters for GSTa2 and epoxide hydrolase enzyme activities $(B, C)$. 


\section{FIGURE 3}

831

832

833

834

835

836

837

838

839

840

841

842

843

844

845

846

847

848

849

850

851

852

853

854

855

856

857

858

859

860

861

862

863

864

865

866

867

868

869

870

871

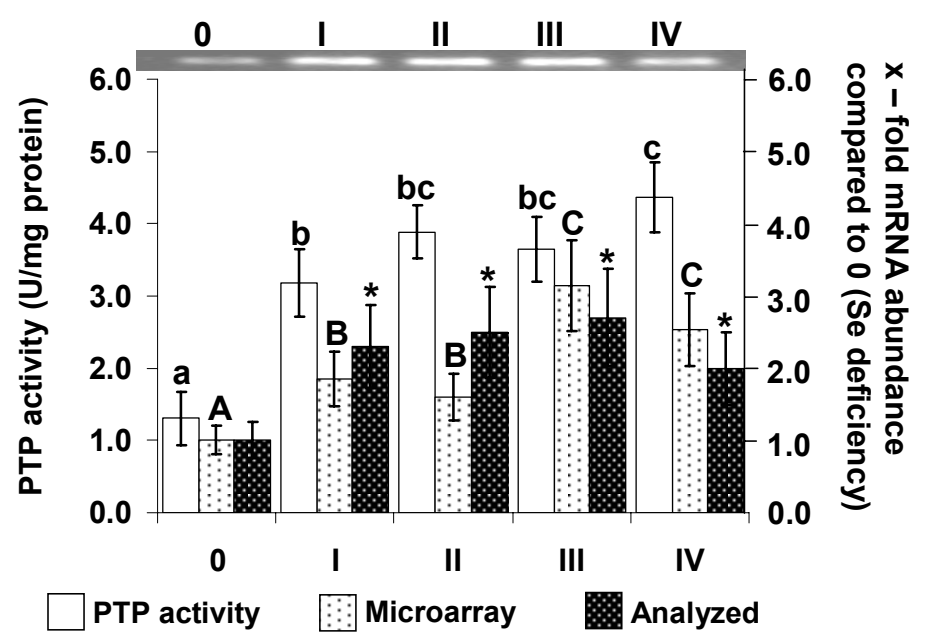

Figure 3 Regulation of PTP1B in rat liver after 8 weeks of Se deficiency (0) compared to Se supplementation with 0.2 or $1.0 \mathrm{mg} \mathrm{Se} / \mathrm{kg}$ diet as selenite (I, III) or selenate (II, IV)

The figure shows PTP1B expression as analyzed by MA analysis and controlled by 2-step RT-PCR as well as PTP enzyme activity

Values are means $\pm S D$. Significant differences between means $(p<0.05)$ are indicated by different small letters for PTP activity, by different capital letters for MA expression data, and by an asterisk for 2-step RT-PCR results. 
872

873

874

875

876

877

878

879

880

881

882

883

884

885

886

887

888

889

890

891

892

893

894

895

896

897

898

899

900

901

902

903

904

905

906

907

908

909

910

911

912

913

914

915

916

917

918

919

920

921

922
FIGURE 4

A)

modification

during intestinal

absorption

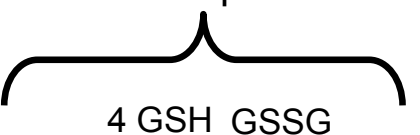

(1) $\mathrm{SeO}_{3}{ }^{2-} \stackrel{\sim}{\longrightarrow}$ GS-Se-SG $\stackrel{\text { GR, TrxR }}{\longrightarrow} \mathrm{H}_{2} \mathrm{Se}$

(2) $\mathrm{H}_{2} \mathrm{Se}$ $\mathrm{MeSeH}$

$\mathrm{MeSeOH}$

(3) $\mathrm{MeSeOH}+$ Prot-SH $\stackrel{-\mathrm{H}_{2} \mathrm{O}}{\longrightarrow}$ Prot-S-Se-Me

in

possible reactions

peripheral tissues

(4) Prot-S-SeMe + GSH $\longrightarrow$ * Prot-S-SG + MeSeH

B)

unmodified

intestinal

absorption

(1) $\mathrm{SeO}_{4}^{2-} \longrightarrow \mathrm{SeO}_{3}^{2-}$

(2) $\mathrm{SeO}_{3}{ }^{2-}+$ Prot-SH $+3 \mathrm{GSH} \longrightarrow$ Prot-S-Se-SG $+2 \mathrm{GS}^{-}+3 \mathrm{H}_{2} \mathrm{O}$

(3) $4 \mathrm{GSH}$ GSSG GSH GSSG GSH GSSG O $\mathrm{O}_{2} \quad \mathrm{O}_{2}^{-}$

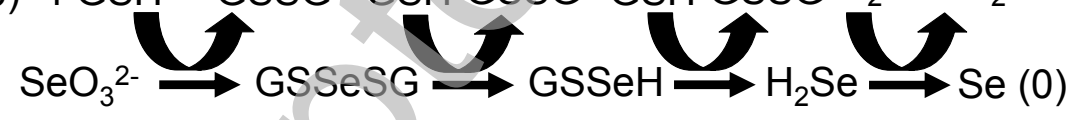

(4) Prot-SH $+\bullet \mathrm{O}_{2}^{-}+\mathrm{H}_{2} \mathrm{O} \longrightarrow$ Prot-S-OH $+\mathrm{OH}^{-}$

(5) Prot-S-OH $+\mathrm{GSH} \longrightarrow{ }^{*}$ Prot-S-SG $+\mathrm{H}_{2} \mathrm{O}$

(6) $\mathrm{H}_{2} \mathrm{Se} \longrightarrow \mathrm{MeSeH} \longrightarrow \mathrm{MeSeOH}$

(7) $\mathrm{MeSeOH}+$ Prot-SH $\stackrel{-\mathrm{H}_{2} \mathrm{O}}{\longrightarrow}$ Prot-S-SeMe

(8) Prot-S-SeMe + GSH $\longrightarrow{ }^{*}$ Prot-S-SG + MeSeH

possible reactions in peripheral tissues

C)

$50 \mathrm{kDa}$ 
923 Figure 4 Pathways and chemical reactions of selenite and selenate during

924

925

926

927

928

929

930

931

932

933

934

935

936

937

938

939

940

941

942

943

944

945

946

947

948

949

950

951

952

953

954

955

956

957

958

959

960

961

962

963

964

965

966 absorption and in peripheral tissues, and reactions leading to proteinthiol-modfications

\section{A) Selenite pathways:}

(1): Selenite reacts already during its absorption with thiol compounds, such as GSH, to form selenodiglutathione and selenotrisulfides.

(1 and 2): Se metabolites delivered to tissues from selenite absorption are selenodiglutathione, selenotrisulfides or hydrogen selenide.

(2 and 3): Pathways by which orally administered selenite can modify cysteine residues in other proteins and thereby lead to changes in differential gene expression derive from the formation of methylselenol from methylselenide, which again can be produced from hydrogen selenide, obtained from the entire reduction of selenite.

(3): Methylselenol may modify cysteine residues in proteins and change the activity of these proteins via thiol modifications such as glutathionylation by methylselenolate release in the presence of glutathione.

\section{B) Selenate pathways:}

(1): Selenate may exert a stronger influence on differential gene expression starting with its unmodified uptake through the small intestine into the organism. During its reduction in peripheral organs the following reactions with cysteine containing proteins are feasible:

(1): In the first reaction step the unreactive selenate (oxidation state $+V I$ ) is reduced in a GR or TrxR dependent reaction to the highly thiol reactive selenite oxidation state +IV.

(2): In the further course selenite (selenious acid) can modify protein thiol groups to selenodiglutathione intermediates.

(3): Excess selenite (selenious acid) reacts with GSH to form hydrogen selenide. In the further course of the reaction in the presence of oxygen, superoxide anion radicals $\left(\mathrm{O}_{2}^{-} \cdot{ }^{-}\right)$and elemental Se can be formed.

(4): The superoxide radical again can attack cysteine residues in proteins and oxidize them to sulfenic acid derivatives.

(5): In the presence of glutathione the sulfenic acid can react to a reversibly inactivated (glutathionylated) protein-thiol compound.

The pathways (6), (7), and (8) in selenate metabolism, starting from hydrogen selenide are identical with the pathways (2), (3), and (4) in selenite metabolism.

*in Figure $4 \mathrm{~A}$ and $\mathrm{B}$ indicate that in selenite metabolism only one pathway leads to the formation of glutathionylated (inactivated) protein intermediates with $\mathrm{SH}$-group containing proteins, whereas this modification can be formed by two pathways during selenate metabolism.

\section{C) Evidence for the higher thiol reactivity of selenate compared to selenite from} diabetic dbdb mice, treated with supranutritional selenite- and selenate doses

The higher protein glutathionylation effected by orally applied selenate compared to selenite, marked with ${ }^{*}$ in Figure 4 A and B can clearly be proven by Western Blot Analysis using an "anti glutathione antibody". The Western Blot shows a distinctly higher glutathionylation of PTP1B, a protein with a catalytically active cystein SH-residue, in dbdb mice treated with supranutritional selenate compared to their selenite treated companions [unpublished results from 17]. Thus this reaction is clear proof of the higher peripheral thiol reactivity of selenate. 